\title{
An Economic Definition of Predation: Pricing and Product Innovation*
}

\author{
Janusz A. Ordover† and Robert D. Willig†
}

Many forms of business conduct have been attacked as predatory since the passage of the Sherman Act in 1890. Neither the courts ${ }^{2}$ nor legal and economic scholars, ${ }^{3}$ however, agree on a general definition of predatory behavior.

Section I of this paper presents a definition of predation ${ }^{4}$ that is economically sound, judicially workable, and broadly applicable to a wide variety of business practices. Section II shows how the well-known costbased tests for predatory pricing can be derived from this general standard. It also clarifies these cost-based tests, and expands their applicability to encompass multi-product firms.

Sections III-V contain the most novel aspect of this paper-the derivation from our general standard of specific tests that distinguish between predatory and procompetitive product innovations. These sections argue that even genuine innovations-new products that in some ways are superior to existing products in the eyes of both engineers and consumers-are in some circumstances anticompetitive. Such innovations do not provide benefits to consumers that are worth the cost, and are motivated solely by

* This article is a substantially revised and expanded version of our paper, An Economic Definition of Predatory Product Innovation, in STRATEgY, PREDATION, AND ANTITRUST ANALYSIS (S. Salop ed. 1981). We are grateful to the National Science Foundation and to the Federal Trade Commission for their financial support of the research reported here. We are also grateful for helpful and stimulating comments from F. Easterbrook and S. Salop, and from E. Bailey, C. Berry, G. Faulhaber, E. Fox, J. Gelman, A. Klevorick, D. Kreps, and F. M. Scherer. Motty Perry provided able research assistance.

+ Associate Professor of Economics, New York University.

tf Professor of Economics and Public Affairs, Princeton University.

1. 15 U.S.C. $\$ \S 1-7$ (1976). Predatory behavior also comes within the purview of the Clayton Act, 15 U.S.C. $\$ \S 12-17$ (1976), the Robinson-Patman Act, 15 U.S.C. $\$ \S 13-13 b, 21 a$ (1976), and the Federal Trade Commission Act, 15 U.S.C. $\S \S ~ 41-58$ (1976).

2. See L. SUllivan, HANDBOOK OF THE LAW OF ANTITRUST 108-13 (1977) (reviewing early predation cases). See also ABA ANTITRUST SECTION MONOGRAPH No. 4, THE ROBINSON-PATMAN ACT: POLICY AND LAW VOLUME I (1980); Hurwitz, Kovacic, Sheehan \& Lande, Current Legal Standards of Predation, in STRATEGY, PREDATION, AND ANTITRUST ANALYSIS (S. Salop ed. 1981) (reviewing post-Areeda-Turner cases) [hereinafter cited as Hurwitz].

3. The recent outpouring of writing on predation has been stimulated by Areeda \& Turner, Predatory Pricing and Related Practices under Section 2 of the Sherman Act, 88 HARV. L. REV. 697 (1975). See Joskow \& Klevorick, A Framework for Analyzing Predatory Pricing Policy, 89 YALE L.J. 213 (1979) (critically analyzing responses to Areeda \& Turner); McGee, Predatory Pricing Revisited, 23 J. L. \& ECON. 289 (1980) (same).

4. See Ordover \& Willig, An Economic Definition of Predation (1981) (unpublished paper on file with Yale Law Journal). 
the monopoly profit attendant on the exit that they induce.

Two types of product innovations are identified as potentially anticompetitive. The first involves the introduction of a new product that is a substitute for the products of a rival firm, and that endangers the rival's viability by diverting its sales. Although this tactic has not been extensively scrutinized in antitrust litigation, it is related to a second type of product innovation that has been the subject of an important and rapidly growing line of cases. Firms adopting this second method of product innovation, a form of "systems rivalry," introduce new systems of components that are incompatible with components manufactured by rivals, and constrict the supply of components that are compatible with those made by rivals. Sections III-V develop workable tests for determining whether or not such tactics are predatory, ${ }^{5}$ and show that these tests can deter anticompetitive product innovation without distorting incentives for procompetitive innovation and without unduly taxing scarce judicial resources. Finally, the Appendix employs the general standard of predatory behavior to analyze the possible anticompetitive effects of product "preannouncements."

\section{A General Standard of Predatory Behavior}

Assuming that businessmen know how their actions affect their profitability and the profitability of their rivals, ${ }^{6}$ predatory objectives are present if a practice would be unprofitable without the exit it causes, but profitable with the exit. Thus, although a practice may cause a rival's exit, it is predatory only if the practice would not be profitable without the additional monopoly power resulting from the exit.

When a firm reduces price below cost, that firm exhibits a predatory objective if it can recover the consequent losses of net revenue only by exercising the additional monopoly power generated by a rival's induced exit. Similarly, the introduction of a new product exhibits a predatory objective if the firm can only recoup its investment by the exercise of such additional monopoly power. It follows that predatory behavior is a response to a rival that sacrifices part of the profit ${ }^{7}$ that could be earned

5. Our tests for predatory product innovation suggest the importance of two factors that have not been analyzed in prior works on predatory behavior. First, the tests require scrutiny of the research and development $(R \& D)$ investment in product innovations. Second, they imply that, in the context of systems rivalry, the predatory act may be the upward repricing or withdrawal of preexisting components that are complementary to the rivals' products.

6. See note 19 infra (relating to plausibility of this assumption); note 20 infra (discussing modifcation of analysis to accommodate uncertainty).

7. Some commentators prefer not to focus on profit-sacrifice in testing for predation, but instead focus on behavior that is detrimental to social welfare. See Scherer, Predatory Pricing and the Sherman Act: A Comment, 89 HARV. L. REV. 869, 883-84 (1976). Easterbrook characterizes the Scherer approach as "nebulous," although he agrees that for a practice to be predatory it must reduce con- 
under competitive circumstances, were the rival to remain viable, in order to induce exit ${ }^{8}$ and gain consequent additional monopoly profit. ${ }^{9}$

An important aspect of the proposed standard is the stipulation that the sacrifice of profit must be assessed with reference to "competitive circumstances." Sacrifice should not be inferred if the incumbent avoids a cartellike response that yields greater profits both for him and for his rival. ${ }^{10}$ Instead, the profitability of the incumbent's actual and alternative responses should be assessed on the assumption that the rival reacts to them in a competitive fashion. A cartel-like response would not benefit the incumbent under this assumption because the rival's competitive reaction would undermine its profitability. Therefore, the proposed standard does not penalize the incumbent for legitimate competitive responses, even if they damage the rival, and the standard does not protect a rival that cannot prosper under competitive circumstances.

For a practice that induces a rival's exit to generate additional monop-

sumer welfare. See Easterbrook, Predatory Strategies and Counterstrategies, 48 U. CHI. L. REV. 263, 264 n.6, 266 (1981). Scherer and Easterbrook disagree sharply, however, as to whether the fact-finder in an antitrust case can perform the requisite welfare calculations. Cf. Joskow \& Klevorick, supra note 3 , at $222,282-87$ (discussing problem of errors in enforcement of welfare-based tests for predation).

8. The definition applies only to behavior that may cause existing rivals to exit the industry; behavior that merely deters entry is beyond its scope.

9. The proposed definition of predation is similar in some respects to that proposed by other authors. For example, Areeda and Turner state that

predation in any meaningful sense cannot exist unless there is a temporary sacrifice of net revenues in the expectation of greater future gains. Indeed, the classically-feared case of predation has been the deliberate sacrifice of current profits for the purpose of driving rivals out of the market and then recouping the losses through higher profits earned in the absence of competition.

Areeda \& Turner, supra note 3, at 698 (footnote omitted). This view of predation was embraced explicitly by the court in Janich Bros., Inc. v. American Distilling Co., 570 F.2d 848, 856 (9th Cir. 1977), cert. denied, 439 U.S. 829 (1978). See R. BORK, THE ANTITRUST PARADOX 144-45 (1978) (predation "provisionally" defined as behavior not profit-maximizing unless rivals are driven from market or chastened not to behave competitively); Baumol, Quasi-Permanence of Price Reductions: $A$ Policy for Prevention of Predatory Pricing, 89 YALE L.J. 1, 5 (1979) (arguing that if quasi-permanence of price cuts is required, established firm will adjust its price in face of entry only if value of resulting competitive gain exceeds long-run permanent reduction in price); Williamson, Predatory Pricing: A Strategic and Welfare Analysis, 87 YALE L.J. 284 (1977) (arguing that predation is intertemporal phenomenon entailing strategic response to actual or potential entry-response is only profitable if it can be rescinded once entry threat subsides or entrant actually exits).

Our definition of predation is superior to the formulation offered by Areeda and Turner for several reasons. First, it explicitly proposes a profit benchmark against which to measure the profit sacrifice. See p. 13 infra. Second, if long-run profits are calculated on the premise of the continued viability of a rival, the proposed definition suggests that predation may entail a sacrifice of long-run profits rather than short-run profits. See note 21 infra. Third, it suggests that analysis of exit inducement should be distinguished from analysis of behavior that deters entry without causing the exit of actual rivals; the profit benchmark that is appropriate to test for predation against actual entrants may not be the benchmark to test for entry deterrence.

10. Such a response might involve a curtailment of output by the incumbent firm to a level low enough for the market to accommodate the entrant's output at a price that allows the entrant to make a profit. An entrant cannot complain of predation, however, if his entry destroys the collusive discipline of an industry and his profits are lower than he anticipated on the basis of industry history. 
oly power, and perhaps thereby to violate the proposed standard of predatory behavior, a market must have several structural characteristics. First, the market must be horizontally concentrated. In an unconcentrated market, there is sufficient competitive discipline from the remaining rivals to preclude monopoly power, irrespective of the exit of one firm.

Second, the market must be protected by a form of entry barriers that we term entry hurdles. These hurdles exist whenever the prospective entrant is cost-disadvantaged relative to the incumbent solely because the incumbent is already functioning as a going concern, and the entrant has not yet committed the requisite resources. ${ }^{11}$ In general, entry hurdles arise when investments are not fully reversible. ${ }^{12}$ The need to incur the irreversible portion of the investment, and thereby to put that amount at risk, confronts the prospective entrant with a cost disadvantage relative to the incumbent whose resources are already committed. ${ }^{13}$ Thus, an incumbent may have an incentive to induce the exit of an entrant, who would then

11. Entry barriers that are not entry hurdles present a firm with a cost disadvantage vis-a-vis an incumbent regardless of whether the firm is a prospective or an actual entrant. For example, a firm with an inferior technology faces a cost disadvantage that would persist after its entry. Thus, it does not matter to the incumbent whether rivalry from such a firm is active or prospective.

12. See Baumol \& Willig, Fixed Costs, Sunk Costs, Entry Barriers, and the Sustainability of Monopoly, 96 Q. J. ECON. 405 (1981) (discussing importance to market organization and performance of distinction between sunk costs and other fixed costs). Baumol and Willig show that the need for an entrant to sink costs can be a barrier to entry that permits incumbents to hold prices above costs. In contrast, fixed costs that are not sunk costs do not impede the power of potential entry to induce efficient operation and pricing on the part of incumbents. See W. BAUMOL, J. PANZAR \& R. WILLIG, CONTESTABLE MARKETS AND THE THEORY OF INDUSTRY STRUCTURE (forthcoming); Bailey, Contestability and the Design of Regulatory and Antitrust Policy, 71 AM. ECON. REV. 178, 178-79 (1981).

13. There are many types of entry hurdles due to the fact that many capital investments are highly specialized, and their value in alternative uses is much lower than their value in the use for which they were originally designed. For such investments, the liquidation value is well below the original cost (adjusted for depreciation), and the difference is a source of risk for the potential entrant.

Before entry, the entrant must foresee an expected return that is sufficiently large to compensate him for the risk of losing the irreversible portion of his investment. For the incumbent, in contrast, the irreversible portion of his investment is already sunk, and the riskiness of his position is concomitantly lower. In addition, the market may have been less risky to the incumbent when he entered because there was less competition at that time. Consequently, the cost of capital to the prospective entrant may be higher than it is for the incumbent. See, e.g., C. VON WEIZSACKER, BARRIERS TO ENTRY 12344 (1980); Williamson, supra note 9, at 295 n.36.

This type of entry hurdle is especially common if there are few prospective buyers in the resale market for the entrant's capital stock, or if the entrant's capital is totally firm-specific and would have no value to other firms. For example, advertising expenditures that are incurred in promoting an entrant's product cannot be recouped if the product fails and the entrant exits the market. Similarly, costs required to assemble a firm's labor force, to establish its reputation, and to acquire its technological and market "know-how" are irreversible firm-specific investments. Costs required to construct a firm's plant also may be irreversible if the plant cannot be resold intact.

Another type of irreversible investment may arise when an entrant has to acquire rights or licenses in order to commence operation. Such acquisition costs will be sunk investments if their unexpired portion is non-refundable. See United States v. Columbia Pictures Indus., Inc., 507 F. Supp. 412 (S.D.N.Y. 1980) (defendants argued that need to acquire costly, non-transferrable pay-television movie rights created entry hurdles into pay-television network programming). 
face an entry hurdle afresh. If there are no entry hurdles, however, there can be no incentives for predation because prospective entrants constrain the market power of the incumbent just as effectively as actual competitors.

A third structural characteristic that is necessary for successful predation is the presence of reentry barriers. ${ }^{14}$ A reentry barrier may be defined as the cost that a firm that has exited a market must incur to resume production. If the firm can costlessly reassemble the physical and human capital that was retooled or dispersed upon the firm's exit, then no reentry barrier exists. Under such conditions, a firm confronted with predatory behavior by a rival can shut down its operations, and costlessly reenter the market when the predator attempts to recoup the profits that he sacrificed during the predatory campaign. If reentry barriers are truly inconsequential, therefore, a predator cannot recoup lost profits because its rivals remain viable even after they cease production. Hence, there can be no motive for predation. ${ }^{15}$

Other structural factors may also be relevant to the threshold assessment of whether successful predation is feasible in a particular market. For example, it is implausible that a relatively small firm could engage in predation against a rival with a strong market position that could not be rapidly eroded. Similarly, it is implausible that a firm with limited financial resources could successfully engage in predation through price cutting against a better-financed rival. ${ }^{16}$

In a market characterized by the structural factors noted above, actual and potential competitors are equally effective at constraining the market power of incumbent firms-whatever the fate of the particular rivals whose exit is at issue-and allegations of predatory behavior in that market should be dismissed. The process of determining whether the market has these characteristics is a structural test ${ }^{17}$ that should be performed

14. If reentry is equivalent to de novo entry, then reentry barriers are the same as entry barriers, including entry hurdles. In some instances, however, reentry may be less costly than new entry because some elements of tangible and intangible capital do not lose all value in the interval between exit and reentry.

15. Bork's argument that successful predation is impossible, or unlikely, see R. BORK, THE ANTI. TRUST PARADOX 149-154 (1978), depends to some extent on the unstated assumption that rivals of the alleged predator do not face significant reentry barriers. Reentry barriers are fairly common and significant, however, and exist to the extent that the capital formerly amassed by a firm has been irreversibly dispersed or depreciated before reentry occurs. For example, salvaged and retooled equipment, dispersed labor force and management, discontinued advertising, and unmaintained reputation can only be replaced or readapted to their former uses at substantial cost. Such costs constitute reentry barriers. See, e.g., G. BECKER, HUMAN CAPITAL (1964) (discussing depreciation of investments in human capital and specific on-the-job training); M. PORTER, INTERBRAND CHOICE, STRATEGY AND MARKET POWER (1976) (discussing advertising).

16. Predatory innovation, however, can entail a precommitment to sunk R\&D costs that renders financial staying power irrelevant.

17. In advocating a structural test, we agree with the two-tier approach suggested by Joskow \& 
prior to the application of tests for predatory behavior. Concededly, one rarely observes markets with no concentration, no entry hurdles, and no reentry barriers, but structural tests nevertheless are useful. In general, the benefit of predation to a firm is smaller the less concentrated its market is (after the exit at issue occurs), the lower the entry hurdles are, and the lower the reentry barriers are. Thus, the relevant structural test is whether the conceivable gains from predation can outweigh the costs to the incumbent of the allegedly predatory conduct. If not, there can be no motive for predation and it is unnecessary to scrutinize allegedly predatory conduct for anticompetitive effect or intent.

In markets in which structural factors permit successful predation, a firm may rationally attempt to induce the exit of a rival in order to gain additional monopoly profits. The mere fact of a rival's exit from such markets, however, does not constitute sufficient proof of predation. To the contrary, exit-inducing actions are not predatory if they are part of legitimate competitive interactions. Differences between firms in efficiency virtually guarantee that some firms will fail in a sufficiently competitive marketplace. These inefficient firms can be induced to exit by actions that efficient firms find profitable regardless of their effects on rivals' viability. Such actions are not predatory.

This distinction between predatory and non-predatory exit-inducing behavior is captured by our proposed standard of predatory conduct. Under that standard, predatory sacrifice of profit is assessed on the premise of the continued viability of the rival. This potentially counterfactual premise assumes that the rival remains able to produce without incurring new start-up costs, whether or not the rival has actually ceased production. Thus, the continued-viability premise is equivalent to assuming the absence of reentry barriers, ${ }^{18}$ and a firm's action entails predatory sacrifice of profit if there is some alternative action that would yield greater profit if there were no reentry barriers. The existence of such an alternative action indicates that the firm's actual action was motivated by the desire for the monopoly profits attendant on the exit of the rival. ${ }^{19}$

Table 1 illustrates these concepts. It lists the present discounted values of the incumbent's profits for three scenarios: the actual action of the incumbent that induces the exit of the rival; the actual action of the incum-

Klevorick, supra note 3, at 242.

18. But see pp. 41-42 infra (allowing for certain analytic complications that arise in the context of systems rivalry).

19. It is unlikely that the alternative action is not known or immediately apparent to the alleged predator. Indeed, in many contexts it is obvious what constitutes such an action. In the case of predatory pricing, for example, an alternative action is a reduction of current output by the incumbent firm, and a commensurate increase in price. In the case of sytems rivalry, the alternative action might be to lower the price on the system components that are compatible with the products of the rival. 
bent under the counterfactual premise that the rival remains viable; and the alternative action of the incumbent that allows the rival to remain viable.

Firm A has an incentive to choose the exit-inducing "actual action," because it yields him a profit of 110 , while the alternative yields only 105 . In this example, the incumbent's choice is predatory because under the counter-factual premise that the rival remains viable, the actual action yields a profit of only 100 , or a profit sacrifice of 5 relative to the alternative action. ${ }^{20}$

Table 1

Incumbent's Profits

\begin{tabular}{lcccc} 
& \multicolumn{2}{c}{ Firm A } & \multicolumn{2}{c}{ Firm B } \\
& Actual Action & Alternative Action & Actual Action & Alternative Action \\
Rival Viable & 100 & 105 & 100 & 95 \\
Rival Exits & 110 & & 110 &
\end{tabular}

Firm B's choice of the actual action is not predatory, however, even though it induces exit. Again, the incumbent has an incentive to make this choice, because it yields him a profit of 110 , while the alternative action yields only 95 . Because the actual action yields a higher profit (100) than the alternative action under the premise of the continued viability of the rival, however, it entails no predatory sacrifice of profit. ${ }^{21}$

Of course, the proposed standard would be difficult to administer if its application required data like those presented in Table 1. Fortunately, one can identify circumstances that are readily observable and that logically imply a predatory sacrifice of profit. Therefore, although the proposed definition of predation is not itself a workable test, it provides a unifying, general, and open-ended standard from which specific and

20. Uncertainty in the rival's response can be readily incorporated into the test for predation by regarding the profit figures as expected values. See Ordover \& Willig, supra note 4 (treatment of predation under uncertainty).

21. Contrary to the analysis of other writers, see Areeda \& Turner, supra note 3 , at 698,703 , this definition of predatory profit sacrifice does not necessarily imply that short-run profit is sacrificed for future monopoly gain. For example, the actual action in Table 1 might earn current period profits of 10, while the alternative action earns only 5 . Despite the fact that the actual action maximizes shortrun profit, however, it is predatory because it would not maximize overall profit if the rival remained viable. Concededly, an effect of this kind is implausible in the context of predatory price-cutting, in which the incumbent sets a low price designed to induce exit and thereby suffers an immediate loss of net revenues. If the predatory action involves investments, however - for example, in plant capacity or in R\&D-the profit sacrifice may occur after the action is taken. In the context of systems rivalry, for example, a predator may respond to entry by shifting from a relatively expensive R\&D program aimed at significant quality improvement of his products to a cheaper R\&D program aimed at exclusionary redesign of his products. Such an investment decision may raise short-run profit and raise expected long-run profit (because of the additional monopoly power), but lower long-run profit under the premise that the new rival remains viable. 
workable tests can be derived. In the case of single product firms, the standard suggests a number of tests akin to those proposed by Areeda and Turner. ${ }^{22}$ Similar tests can be derived for multiproduct firms.

\section{Application of the General Standard to Predatory Price-Cutting}

The well-known cost-based tests for predatory price-cutting, and useful new variants of these tests, can be derived from the proposed standard.

\section{A. Price Floors for Single Product Firms}

Consider, as a stereotype, a dominant incumbent firm that drops its price in response to entry, and thereby endangers the viability of the entrant. Our proposed standard of predatory behavior requires first that the structure of the relevant market be examined for concentration, entry hurdles, and reentry barriers. If the market exhibits all of these structural features, and if the price cut raises the probability of the entrant's exit to a dangerous level, then the standard directs attention to the question of whether the incumbent's response to entry, which includes his decisions about price, output, capital investment, and marketing activities, entails a predatory sacrifice of profit. If an alternative response would earn greater profit for the incumbent under the premise of the continued viability of the rival, a finding of predation would be appropriate.

In the simplest possible case, the issue of whether the incumbent's response to entry entails predatory sacrifice of profit reduces to the issue of whether an alternative response, less threatening to the entrant's viability, would yield a higher level of current profit under competitive circumstances. This simple case arises when the response at issue has no impact on the incumbent's future profits apart from effects on the degree of competition offered by the rival. For this condition to hold, there must be no intertemporal demand effects, such as those that motivate promotional pricing, and current output and investment must have no effect on future profitability. Such effects on future profits may sometimes exist, however, and although the proposed standard can readily account for them, ${ }^{23}$ we

22. Areeda \& Turner, supra note 3.

23. For example, when an incumbent's response includes a change in his investment policy, an effect on future profits will typically result. Workable tests that apply when the incumbent's response includes investment or disinvestment in capital facilities can be derived from the general standard. See Ordover \& Willig, supra note 4, at 80 . See also pp. 26-28 inra (discussing responses that include R\&D investment).

Areeda \& Turner doubt whether such effects on future profitability can be incorporated into the analysis in a practical manner. See Areeda \& Turner, supra note 3, at 718-19. Concededly, neither the legal and economic commentators nor the courts have heretofore developed a theoretical framework with which to analyze such practices. Our framework can be adapted to this purpose, however, and once it is so adapted, fact-finders will be able to determine whether it can be applied in a practical manner. 
assume for simplicity that under the continued-viability premise, the response to the rival affects only the current profits of the incumbent. Then, the actual response of the incumbent exhibits predatory sacrifice of profit if an alternative price and output response would increase the incumbent's current profits under competitive circumstances and would lower the probability of the rival's exit.

When the response to entry involves price-cutting, the relevant alternative responses entail smaller levels of output than that actually chosen by the incumbent, say by $\delta$, and commensurately higher prices. Of course, the price that would result under competitive circumstances from an output reduction of $\delta$ depends upon the precise nature of market demand and rivals' production costs. Under the plausible assumption that an output reduction does not result in a lower price, however, a cost-based test for predatory profit sacrifice does not require a determination of the new price level. Instead, observe that the incumbent's cutback of $\delta$ from his actual level of production would reduce his revenues by no more than his original price, $\mathrm{p}$, multiplied by the cutback, $\delta{ }^{24}$ If the incumbent's output cutback would not affect price at all, the revenue reduction is exactly equal to $\mathrm{p} \delta$. If the cutback would cause the price to rise, the revenue reduction would be less than $\mathrm{p} \delta$ because of the additional revenue earned on the remaining units of output.

The output cutback of $\delta$ from the incumbent's actual production, which is less damaging to the rival, will increase the incumbent's profits under the continued viability premise if it yields him a savings of production costs that exceeds the reduction of the incumbent's revenues. Thus, predatory sacrifice of profit is present if the cost saving from the hypothetical output cutback is larger than $\mathrm{p} \delta$-an underestimate of the revenue reduction if price increases, and an exact estimate if price remains constant. Concomitantly, predatory sacrifice is present if the incumbent's actual price, $p$, is less than the average savings in costs due to the output cutback, where the average is taken over the size of the hypothetical cutback, $\delta$, for any possible value of $\delta .^{25}$

Several specific values of $\delta$ narrow this general test to especially useful cost-based price floors. For the value of $\delta$ that corresponds to elimination of the incumbent's entire output, the test for predatory sacrifice is whether the incumbent's price is below the average avoidable cost of the product

24. Let $\mathrm{p}^{\prime}$ and $\mathrm{p}$ be the alternative and actual prices, respectively, and let $\mathrm{q}^{0}-\delta$ and $\mathrm{q}^{0}$ be the alternative and actual levels of output. Then, the reduction in revenues is $p q^{0}-p^{\prime}\left(q^{0}-\delta\right)$. But, with $p^{\prime}$ $\equiv p$, this expression is less than or equal to $\left.\mathrm{pq}^{0}-\mathrm{p}^{\circ} \mathrm{q}^{0}-\delta\right)=\mathrm{p} \delta$, as stated in the text.

25. If $\mathrm{C}\left(\mathrm{q}^{\circ}\right)$ and $\mathrm{C}\left(\mathrm{q}^{\circ}-\delta\right)$ denote total production cost for output levels $\mathrm{q}^{\circ}$ and $\mathrm{q}^{\circ}-\delta$, respectively, predatory sacrifice is present if $p<\frac{C\left(q^{0}\right)-C\left(q^{0}-\delta\right)}{\delta}$. 
line in question. For the value of $\delta$ that corresponds to the smallest possible output cutback, the test is whether the price is below the marginal (avoidable) cost. ${ }^{26}$

Thus, the cost-based tests for predatory pricing advanced by other writers may be derived from our proposed standard. ${ }^{27}$ But contrary to the suggestion of Areeda and Turner that the average cost price floor is merely an approximation to the theoretically superior marginal cost price floor, ${ }^{28}$ our standard implies that both average cost and marginal cost define correct price floors. ${ }^{29}$ In particular, if the incumbent's price is below marginal cost, a slight reduction of the incumbent's output flow would raise profits under the premise of the continued viability of the rival. If the price is below average cost, an elimination of the incumbent's output flow would raise his profits under the same premise. Because either of these alternatives is less threatening to the rival's viability than the incumbent's actual response, both define correct tests of predatory sacrifice under the proposed standard. ${ }^{30}$

Our approach to the derivation of these cost-based tests also clarifies the appropriate cost concepts. Whatever the cost-based test at issue, it is the cost saving from an output contraction that must be compared with the associated revenue reduction. Hence, advertising and other marketing costs, for example, should be included in the average cost test to the extent that they can be avoided if the incumbent ceases production.

Similarly, there are circumstances in which capital costs should be in-

26. Other hypothetical cutbacks yield additional cost-based price floors that are germane to various circumstances. For example, if the incumbent increases his output following the rival's entry, an interesting and important hypothetical cutback is equal to the post-entry output expansion. The resultant cost-based test for predatory sacrifice is whether the actual price is below the average cost of the post-entry output expansion. See Ordover \& Willig, supra note 4.

27. Cost-based tests for predatory pricing were first derived by Areeda \& Turner, supra note 3, and amplified by Baumol, supra note 5 , and Joskow \& Klevorick, supra note 3. Leading court cases that have applied these tests include Berkey Photo, Inc. v. Eastman Kodak Co., 603 F.2d 263 (2d Cir. 1979), cert. denied, 444 U.S. 1093 (1980); Janich Bros., Inc. v. American Distilling Co., 570 F.2d 848 (9th Cir. 1977), cert. denied, 439 U.S. 829 (1978); International Air Indus., Inc. v. American Excelsior Co., 517 F.2d 714 (5th Cir. 1975), cert. denied, 424 U.S. 943 (1976); California Computer Prods., Inc. v. IBM, 613 F.2d 727 (9th Cir. 1979); Transamerica Computer Co. v. IBM, 459 F. Supp. 626 (N.D. Cal. 1978), 481 F. Supp. 965 (N.D. Cal. 1979), appeal docketed, No. 80-4048 (9th Cir. Jan. 31, 1980); ILC Peripherals Leasing Corp. v. IBM Corp., 458 F. Supp. 423 (N.D. Cal. 1978), affd. sub nom. Memorex Corp. v. IBM, 636 F.2d 1188 (9th Cir. 1980). See also Pacific Eng'r \& Prod. Co. v. Kerr-McGee Corp., 551 F.2d 790 (10th Cir.), cert. denied, 434 U.S. 879 (1977). A useful and up-to-date compendium of predatory pricing cases is Hurwitz, supra note 2.

28. Areeda \& Turner, supra note 3, at 716-18.

29. This result, of course, depends upon our stated assumption that relevant alternative responses by the alleged predator have no effects on his future profitability, other than those that stem from the exit of rivals. See pp. 15-16 supra.

30. The relative stringency of these two tests will depend upon the circumstances in which they are applied. For example, if there are economies of scale in avoidable costs, then the average cost test is the more stringent one--that is, it defines a higher price floor than the marginal cost test. 
cluded in the calculation of the cost-based price floors. ${ }^{31}$ If capital has alternative uses, either internal or external to the firm, output contractions can save capital costs by freeing equipment for use elsewhere. These avoidable capital costs should always be included in the calculation of price floors. Moreover, even if capital costs are not avoidable after they are first incurred, they should still be included in the price floor that applies when the firm has expanded output as part of its allegedly predatory conduct - the firm could have avoided such costs by maintaining the original level of output. Capital costs should be included to some extent under these circumstances regardless of whether the firm expanded its capital stock concurrently with its output expansion. ${ }^{32}$ Thus, although output expansion in response to entry is not necessarily predatory under the proposed standard, output expansion can lead to a higher cost-based price floor, and to a more stringent test for predatory price cutting. ${ }^{33}$

Given the appropriate cost concepts, these tests for predatory pricing protect and enhance competition without simultaneously interfering with its workings. The tests condemn behavior that induces exit and that is not a part of the normal competitive process, but they do not mistake a normal competitive response for a predatory response-competitive responses entail no sacrifice of profit under the premise of the continued viability of the rival.

Furthermore, one can demonstrate in a variety of theoretical settings that the proposed standard protects rivals that would profitably produce in the socially optimal allocation of production among extant firms, but does not protect inefficient firms that would not profitably produce at the social optimum. ${ }^{34}$ Suppose, for example, that both the incumbent and the rival have constant marginal and average costs. If the costs of the incumbent are lower than those of the rival, then the latter would not profitably produce in the socially optimal allocation of productive resources. Without violating the standard of predation, therefore, the incumbent can induce the rival's exit by lowering price to a level just below the rival's cost.

31. See Ordover \& Willig, supra note 4 , at 81 .

32. If the firm expanded its capital stock concurrently with the output expansion, then an alternative and less damaging response to its rival would be to lower output and to lower or at least postpone investment. Under these circumstances, the added capital costs are directly attributable to the actual output expansion. If the output expansion is not accompanied by additional investment, then the price floor calculation should still include any increase in the costs of producing the preexpansion level of output caused by the congestion of capital facilities. A conservative estimate of this amount is the cost of the capital that eventually would be purchased to alleviate such congestion.

33. See Williamson, supra note 5, at 114-16 (arguing that output expansion by incumbent firm following entry of rival may be predatory).

34. Application of the proposed standard does not necessarily raise the level of social welfare if the incumbent and his rivals do not actively compete. In fact, one can construct examples in which all extant firms exhibit non-competitive behavior, and although the standard may protect an existing firm from induced exit, such exit would raise social welfare. 
Because a higher price would be undercut by the rival, no alternative price, less damaging to the rival, earns the incumbent greater current profit under competitive circumstances. A price just below the rival's cost entails no profit sacrifice, therefore, and it does not violate our standard of predation even though it induces exit.

Now suppose that the costs of the incumbent exceed those of the rival. Then only the rival would profitably produce at the social optimum. The incumbent nonetheless may have an incentive to induce the exit of the rival to gain market power and to permit prices in excess of the rival's costs. If his staying power is greater than the rival's, ${ }^{35}$ it is possible that the incumbent will successfully induce exit, and thus reduce social welfare because, by hypothesis, the rival should produce at the social optimum. An exit-inducing action by the incumbent under these conditions, however, entails predatory sacrifice, because a price below the rival's cost will cause the incumbent to earn a negative profit that is less than his profit under any one of the following alternative responses that are less damaging to the rival: a small cutback in output; a total elimination of production; or an increase in price to a level that covers production costs. Of course, if the incumbent's actual action succeeds in driving the rival out of the market, it may be the incumbent's most profitable action. Under the premise of the continued viability of the rival, however, the actual price is not the most profitable price, and it is predatory under the proposed standard. ${ }^{36}$

35. The incumbent may have greater staying power than the more efficient rival if he has better internal financing or has more tangible assets available to secure debt. Concomitantly, external financing is not always available to the rival simply because he is more efficient. This fact does not necessarily reflect imperfections in the operation of capital markets, but rather it may reflect the intrinsic inability of outsiders to appraise the market situation with certainty, and their resulting unwillingness to provide funds without charging a substantial risk premium.

36. To elaborate on the welfare analysis of the proposed standard, consider an industry in which the socially optimal allocation of productive resources requires production by an arbitrary number of firms, $n$, indexed by $i=1,2, \ldots, n$. At the social optimum, each firm charges the market price, $p^{*}$, produces $q_{i}^{*}$ where $C_{i}^{\prime}\left(q_{i}^{*}\right)$, the firm's marginal production cost, is equal to $p^{*}$, and earns a nonnegative profit given by $\pi_{i}^{*}=p^{*} q_{i}^{*}-C_{i}\left(q_{i}^{*}\right)>0$. To induce the exit of a rival who would produce at this social optimum, it is necessary that a firm (say firm l) set price at a level below $\mathrm{p}^{*}$, or set price at $\mathrm{p}^{*}$ while producing more output than $\mathrm{q}_{1}^{*}$, thereby leaving the rival with smaller demand than it needs to cover its costs. Otherwise, the rival, $i$, would earn at least $\pi_{i}^{*}>0$, and would continue to produce.

Either of these exit-inducing tactics, however, entails a predatory sacrifice of profit on the part of firm 1. An alternative action for frm 1 , less damaging to the rival, is to charge $\mathrm{p}^{*}$ and produce $\mathrm{q}_{1}^{*}$. The competitive response to this action by each other firm, $j$, is to produce $q_{j}^{*}$ and charge $p^{*}$, so that $\mathrm{p}^{*}$ indeed will be the market price under competitive circumstances.

The price $p^{*}$ and the output $q_{1}^{*}$ earns a higher profit for firm 1 , under competitive circumstances and with the continued viability of the rival, than a price below $p^{*}$ or an output above $q_{1}^{*}$ at price $p^{*}$ : Define $\pi_{1}^{*}(p)$ to be the maximium profit that firm 1 can earn if the market price is $p$. This maximum corresponds to a choice of output $\mathrm{q}_{1}^{*}(\mathrm{p})$ at which marginal cost, $\mathrm{C}_{1}^{\prime}\left[\mathrm{q}_{1}^{*}(\mathrm{p})\right]$, is equal to $\mathrm{p}$. Therefore, $\pi_{1}^{*}=\mathrm{p}^{*} \mathrm{q}_{1}^{*}-\mathrm{G}_{1}\left(\mathrm{q}_{1}^{*}\right)=\pi_{1}^{*}\left(\mathrm{p}^{*}\right)$. Moreover, because $\pi_{1}^{*}(\mathrm{p})$ decreases as $\mathrm{p}$ decreases, if firm 1 sets a price that is lower than $\mathrm{p}^{*}$, or produces an output that is greater than $\mathrm{q}_{1}^{*}$ at the price $\mathrm{p}^{*}$, it will earn a profit smaller than $\pi_{1}^{*}\left(\mathrm{p}^{*}\right)$, the profit it would earn at the social optimum. The exit-inducing tactics 


\section{B. Price Floors for Multiproduct Firms}

This section develops a test for predatory price-cutting that is applicable to multiproduct firms. ${ }^{37}$ It shows how cost-based price floors should be adjusted for demand interrelationships between products.

The analysis again focuses on the response by a dominant incumbent firm to the entry of a new rival. The incumbent is assumed to be a multiproduct firm, however, and the product whose price or output level is allegedly predatory is assumed to be cross-elastic with another of the incumbent's products. The multiproduct nature of the firm does not alter the basic test for predatory sacrifice-whether an output contraction of size $\delta$, along with a commensurate increase in price, would increase the current profit of the incumbent under competitive circumstances.

As above, assume that the output contraction does not cause price to fall, so that $\mathrm{p} \delta$ is a conservative estimate of the loss of revenue from the sales of the product, and the associated cost savings less $\mathrm{p} \delta$ is an overestimate of the increase in the incumbent's current profit on the product. In the multiproduct case, however, the effects of the output contraction on the incumbent's profit also depend upon its effects on revenue and production costs for the cross-elastic product. Let $w$ be the initial price of the cross-elastic good before the output contraction, and let $\Delta y$ be the change in sales of the cross-elastic good due to the output contraction, $\delta$. An estimate of the effect of the output contraction on profit from sales of the cross-elastic good that leads to a conservative test for profit sacrifice is the approximate change in revenue, $w \Delta y$, less the change in production cost for the cross-elastic good attributable to the change in its output. ${ }^{38}$

Predation exists under our standard if the conservative estimate of the loss of direct revenues from the hypothetical output contraction, $\mathrm{p} \delta$, is less than the sum of the direct cost saving from the contraction and the estimate of the net effect on profit from the sales of the cross-elastic product.

of setting price below $\mathrm{p}^{*}$ or producing output greater than $\mathrm{q}_{1}^{*}$ at price $\mathrm{p}^{*}$, therefore, earn less profit under competitive circumstances and with the continued viability of the rival than the alternative of producing $\mathrm{q}^{*}$, at price $\mathrm{p}^{*}$. Hence, the use of exit-inducing tactics against a firm that would produce at the social optimum entails predatory sacrifice of profit under the proposed standard of predation.

On the other hand, a firm can induce the exit of another firm that would not produce at the social optimum without predatory sacrifice of profit. In this model, such a result can be derived by analyzing a series of price reductions and output increases culminating in the attainment of the optimum. Under competitive circumstances, these actions by firms that would survive at the optimum increase their profits, and hence do not entail predatory sacrifice.

37. The courts have had difficulty with this problem. See Transamerica Computer Co. v. IBM, 459 F. Supp. 626, 631-32 (N.D. Cal. 1978) (suggesting that adjustments to cost-based tests to reflect cross-elasticity are impermissible as a matter of law).

38. Considering $w$ to be unchanged leads to a conservative test for sacrifice because if the output contraction of $\delta$ increases profit (under the viability premise) with $w$ unchanged, then it would also increase profit with $w$ readjusted to maximize profit concurrently with the output contraction. $C f$. $P$. SAMUELSON, FOUNDATIONS OF ECONOMIC ANALYSIS (1947) (discussion of Le Chatelier principle). 
Equivalently, the test for predatory sacrifice is whether the price at issue is below the cost saving from the hypothetical cutback, averaged over the size of the cutback, plus an adjustment for the cross-elastic effects. This adjustment is the ratio of the induced output change, $\Delta y$, to the cutback, $\delta$, multiplied by the margin between the price, $w$, and the average cost change associated with the cross-elastic good. ${ }^{39}$

To analyze the effects of this adjustment on the cost-based price floors for multiproduct firms, relative to the floors that would be used for single product firms, assume that the price of the cross-elastic good is not less than its average incremental cost. ${ }^{40}$ If the cross-elastic product is a substitute $^{41}$ for the good in question, the adjustment for cross-elasticity raises the cost-based price floor because price cuts have an additional negative effect on the incumbent's current profits due to the diversion of profitable sales from the substitute product. If the cross-elastic product is a complement to the good in question, however, the adjustment lowers the price floor because price cuts have an additional positive effect on the incumbent's current profits by stimulating profitable sales of the complementary product. In both cases, the size of the adjustment to the price floor is greater, the larger is the mark-up of price over cost on the cross-elastic good, and the more sensitive are the sales of the cross-elastic good to the price and output of the good in question. If there is no significant cross-elastic effect, or if there is no significant mark-up over average incremental costs on the cross-elastic good, the adjustment for cross-elastic effects may be ignored. ${ }^{42}$

39. To be precise, let $q^{\circ}$ and $y^{\circ}$ be the actual output levels of the two goods. An output contraction of $\delta$ would increase the incumbent's current profit if $p^{0}\left(q^{0}-\delta\right)+w\left(y^{0}+\Delta y\right)-C\left(q^{0}-\delta, y^{0}+\Delta y\right)>$ $p q^{0}+w y^{0}-C\left(q^{0}, y^{0}\right)$, where $C$ now denotes the multiproduct cost function. With $p^{0} \geq p$, a sufficient condition for this inequality to hold is:

$$
\mathrm{p}<\frac{\mathrm{C}\left(\mathrm{q}^{0}, \mathrm{y}^{0}\right)-\mathrm{C}\left(\mathrm{q}^{0}-\delta, \mathrm{y}^{0}\right)}{\delta}+\frac{\Delta \mathrm{y}}{\delta}\left[\mathrm{w}-\frac{\mathrm{C}\left(\mathrm{q}^{0}-\delta, \mathrm{y}^{0}+\Delta \mathrm{y}\right)-\mathrm{C}\left(\mathrm{q}^{0}-\delta, \mathrm{y}^{0}\right)}{\Delta \mathrm{y}}\right]
$$

40. This assumption is likely to be correct because the price of the cross-elastic good is not being tested for predation - absent predatory intent, it would not pay the incumbent to maintain that price below average incremental cost.

41. Two goods are "substitutes" if an increase in the price of one good increases the demand for the other. For example, mid-size Chevrolets and mid-size Buicks are likely to be substitutes. Two goods are "complements" if an increase in the price of one good decreases the demand for the other. Computer peripherals and central processing units are likely to be complements, as are cameras and film.

The degree of substitutability or complementarity between two goods is measured by their crossclasticity of demand, which equals the percentage change in the quantity demanded of one commodity that results from a one-percent change in the price of the other commodity. If the cross-elasticity is positive, then the two goods are substitutes; if it is negative, then the two good are complements.

42. It is not correct, however, to base the tests of price predation for a multiproduct firm on a product-specific average cost. For a multiproduct firm, average cost is not a meaningful concept, because its calculation implicitly requires that fixed costs, including some R\&D costs, be allocated among product lines. There are no economically sound methods for allocating such common costs, however, and as shown above, see note 29 supra, average incremental cost is the appropriate measure of a product's cost for purposes of predation analysis. See In Re Coal Rate Guidelines-Nationwide Proceedings before the ICG, Ex Parte No. 347 (Sub-No. 1) (May 11, 1981)(statement of W. Baumol 


\section{Predatory Product Innovations}

Predatory pricing is only one of the strategies that a firm may use to induce the exit of a competitor. The introduction of a new product can also be anticompetitive and predatory. Indeed, such a tactic may be more effective than predatory price-cutting as a way of inducing exit. ${ }^{43}$ of course, the introduction of a new product can also be procompetitive, as well as directly beneficial to consumers who prefer the new product to the existing ones.

Unlike a price cut, however, the introduction of a new product is a composite strategy. It involves at a minimum the following fundamental decisions: (a) the choice of the product design; (b) the choice of the time to announce the new product; (c) the choice of the price for the new product; (d) the choice of the size and content of research and development (R \& D) and promotional budgets; and (e) in a multiproduct firm, the choice of the associated adjustments in the prices of existing products. Each of these choices can affect the viability of competitors. To test the introduction of a new product for predation, therefore, it is necessary to scrutinize these choices both singly and jointly as components of the overall strategy. ${ }^{44}$

Our analysis considers two tactics that may or may not be predatory. One tactic is the introduction of a new product that is a substitute for the products of the rival firm, and that endangers the rival's viability by diverting its sales. The second tactic, employed in the context of systems rivalry, involves the constriction of the supply of components that consumers must purchase in order to use the product of the rival, and a concur-

\& R. Willig, economists); Braeutigam, An Analysis of Fully Distributed Cost Pricing in Regulated Industries, 11 BELL J. ECON. 182 (1980); Cole, A Note on Fully Distributed Cost Prices, 12 BELL J. ECON. 329 (1981). But see Transamerica Computer Co. v. IBM, 459 F. Supp. 626, 631 (arguing that appropriate method of cost allocation is factual question).

43. Product innovation may be more effective than price-cutting in inducing the exit of a rival because the associated costs to the firm are largely fixed and irreversible. After a firm commits the requisite $R \& D$ and other fixed costs, the remaining reversible costs of the product introduction may be so small that the firm would not abandon its tactic whatever the rival's response. Aware of this fact, rivals may quickly exit. In contrast, a rival's dogged refusal to exit can always motivate a firm to rescind a price cut. Thus, rivals may persevere in order to test the resolve of the price-cutter.

Areeda and Turner argue against extensive antitrust scrutiny of investments in new products or product lines. See Areeda \& Turner, supra note 3, at 719, 722, 730 . Even in the absence of antitrust sanctions, however, manipulation of the product set can be more effective than price-cutting as an anticompetitive tactic. There is a strong policy reason not to exclude the introduction of new products from antitrust scrutiny, therefore, unless reasonable tests for predation are infeasible.

44. Under the Areeda-Turner test, a new product is not predatory if its price satisfies the de minimis requirement that it equal or exceed the short-run marginal cost (or, if marginal costs cannot be computed, the short-run average variable cost). Short-run marginal cost and short-run variable cost, however, are not correct cost-based price floors for new products. To illustrate, consider a new product whose demand in the presence of competition permits a price above these foors, but does not permit a price high enough to recoup the requisite $R \& D$ outlays. The social benefits from such an R\&D investment are questionable. See pp. 26-28 infra. In addition, a firm may undertake such an R\&D investment in order to induce the exit of rivals, increase its monopoly power, and thereby recoup $R \& D$ outlays through price increases made possible by the weakening of competition. 


\section{Predatory Product Innovation}

rent introduction of new systems components that provide consumers with an alternative to the rival's products.

Each of these tactics can have three effects. First, each may increase the variety or the quality of the products available to consumers. Second, each may facilitate the procompetitive entry of new firms, or the procompetitive expansion of the number of competing products. Third, however, each may undermine competition by eliminating rivals whose viability is essential to competition.

\section{A. The Introduction of Substitute Products as a Form of Predation}

This section discusses in detail the phenomenon of competition through the introduction of substitute products. Although the introduction of substitutes has not been a subject of extensive antitrust scrutiny, the tests for predatory innovation developed in this section are necessary to the development of tests for predatory systems rivalry, which has been the subject of extensive litigation.

\section{Introduction to Theoretical and Practical Issues}

The prototypical instance of predation through the introduction of a substitute product may be described as follows. The dominant manufacturer of widgets in a concentrated industry introduces a new and superior model. The price of the new model is set low enough to induce a large percentage of buyers to switch from previous models, among which there is significant competition. Because of declining sales and declining net revenues, rival manufacturers abandon the production of widgets, and disperse their productive assets. After exit occurs, the innovating firm readjusts its prices and earns additional monopoly profits that are protected by entry hurdles and reentry barriers.

It is not surprising that predatory product innovation may occur in a scenario of this kind. If a dominant firm can engage in predatory pricecutting, with the quality of its product left unchanged, an obvious alternative tactic is to improve the product's quality without changing its price. Because consumers may divert their purchases of the rival's goods to the new product in response to the quality improvement, the qualitative effect on a rival of predatory product innovation is much the same as the qualitative effect of predatory price-cutting.

An important conceptual distinction between the two tactics, however, is that although predatory price-cutting may reduce price below cost, predatory product innovation may increase cost above price. Such a cost increase may consist of an increase in variable cost, an increase in expenditure for R\&D and other fixed costs necessary to bring the new product 
to market, or both. It is the second group of costs that raise practical and theoretical issues beyond the issues already discussed in connection with predatory pricing. The proposed general standard of predation, however, does suggest a proper test for predatory product introduction that incorporates such costs. Essentially, the test inquires whether $R \& D$ and other fixed outlays that are incurred for the new product can be recouped through profits on the new product, under the premise of the continued viability of the rival. Of course, an important problem in the application of this test is to distinguish between predatory $R \& D$ expenditures, and R \& D expenditures for unsuccessful projects that are undertaken for legitimate purposes. These practical aspects of implementing the test are discussed in Section III. C below, after a demonstration of the welfare optimality of the test in the context of a simple model.

\section{A Model of Predation through Substitute Product Innovation and its Welfare Implications}

Consider the following scenario: Immediately after the entry of a rival, the dominant firm (firm $A$ ) sells $\mathrm{N}_{\mathrm{A}}$ units of output, and the rival firm (firm B) sells $N_{B}$ units of a product that substitutes perfectly in the perceptions of consumers for the output of firm A. Each firm receives a price of $p$ per unit, and each consumer values ${ }^{45}$ a unit of either firm's product at $b$. The unit production cost for firm $A$ is $c_{A}$, which is less than or equal to the unit production cost for firm $B, c_{B}$. The rival, firm $B$, equates price and unit cost so that $c_{B}=p$.

Suppose that in response to the entry of firm B, firm A expends the sum of $\mathrm{R}$ on an annual basis ${ }^{46}$ to introduce a new substitute product. The new product yields to each consumer a value of $b^{\prime}$ per unit, and has a variable unit production cost of $c_{A}^{\prime}$. Firm $A$ markets the new product at the highest possible price that induces all consumers to purchase the new product instead of the old product. This price, $p^{\prime}$, is just below $b^{\prime}-b+p$ because, at this level, the net benefit to a consumer from purchasing the new good, $b^{\prime}-p^{\prime}$, just exceeds the net benefit from purchasing the old good, $b-p .{ }^{47}$ As a result, firm B loses all of its sales and exits from the market. Afterwards, in the presence of reentry barriers, firm A can raise its price without concern for the competition of firm B, and can thereby earn

45. The "value" of one unit of a product to a consumer is equal to the maximum amount the consumer will pay for it.

46. That is, the actual $R \& D$ expenses of firm $A$ are equivalent in present value to annual expenses of $R$ over the anticipated life of the new product. Thus, $R$ can be viewed as the present value of R\&D expenditures multiplied by the sum of the rate of return and the appropriate depreciation rate.

47. That is, if $\mathrm{p}^{\prime}<\left(\mathrm{b}^{\prime}-\mathrm{b}+\mathrm{p}\right)$, then $\mathrm{b}^{\prime}-\mathrm{p}^{\prime}>\mathrm{b}^{\prime}-\left(\mathrm{b}^{\prime}-\mathrm{b}+\mathrm{p}\right)=\mathrm{b}-\mathrm{p}$. 
greater profit.

Under the proposed general standard of predation, the introduction of the new product is not predatory if the investment required to introduce the product is recoverable under the premise of the continued viability of firm B. Under that premise, B continues to make its product available at the competitive price of $p$, and firm A can obtain a price no higher than $\mathrm{p}^{\prime}$ $=b^{\prime}-b+p$ for the new good. Then, under the continued viability premise, one can show that the annualized investment cost of $R$ is exceeded by the increase in firm A's net revenues from the new product if and only if the investment is socially desirable. That is, the social benefits from the new product exceed its costs if and only if the introduction of the product is profitable under the premise of the continued viability of the rival. ${ }^{48}$ Thus the proposed test for predation is indeed conducive to social welfare.

Of course, our demonstration of the welfare optimality of the proposed predation standard rests on the assumptions of this simple model. Nevertheless, the analysis has a number of general implications. First, even if a new product is successful in the market, it may either increase or decrease social welfare, depending upon the magnitude of $R \& D$ costs and other investments. Second, a dominant firm may profit from the introduction of a new product, whether or not it is socially beneficial, if it induces the exit of a rival and thereby increases the firm's monopoly power. Third, application of the proposed standard of predation may reduce the incentives for anticompetitive product innovation, without diminishing the incentives for procompetitive innovations.

\section{General Application of the Proposed Standard}

General application of the proposed standard to the introduction of substitute products raises a number of issues that require further discussion. Under the continued viability premise, the assessment of the profitability of a new product must take account of the loss in net revenues from the innovator's old product. In other words, the introduction of a new substitute product may be predatory if the revenues from its sales fail to exceed the incremental costs of its production plus the reduction in net revenues

48. The algebraic proof is as follows: Prior to the introduction of the new product and the investment in its development, firm A earns a profit of $\pi_{0}=N_{A}\left(p-c_{A}\right)$. After the new product is introduced, and under the continued viability premise, the new price is $p^{\prime}=b^{\prime}-b+p$. Firm $A$ displaces the sales of firm $B$, and hence firm $A$ 's new profit level under the continued viability premise is $\pi_{1}=\left(N_{A}+N_{B}\right)$ $\left(b^{\circ}-b+p-c_{A}^{\prime}\right)-R$. If the innovation is to be profitable under the continued viability premise, then $\pi_{1^{-}}$ $\pi_{0}>0$. This inequality implies that $N_{A}\left(b^{\prime}-b+c_{A}-c_{A}^{\prime}\right)+N_{B}\left(b^{0}-b+p-c_{A}^{\prime}\right)-R>0$. Recall that $p=c_{B}$. Then, this inequality can be written as $N_{A}\left[\left(b^{\prime}-c_{A}^{\prime}\right)-\left(b-c_{A}\right)\right]+N_{B}\left[\left(b^{\prime}-c_{A}^{\prime}\right)-\left(b-c_{B}\right)\right]-R>0$. The expression on the left-hand side, however, is precisely the change in net social welfare due to the investment and new product introduction, as measured by the sum of consumers' and producers' surplus. Thus, $\pi_{1^{-}}>>0$ holds if and only if the investment and innovation increase social welfare. 
caused by the diversion of sales from the preexisting products of the innovator. If revenues fall short of this level, there is prima facie evidence that the product introduction entails a predatory sacrifice of profit under the continued viability premise. ${ }^{49}$

The existence of a profit sacrifice, however, is not itself sufficient for a finding of predation. The likelihood of the rival's exit must be substantially raised by the product introduction, and the additional monopoly profit that would accrue to the innovator after the exit of the rival must be sufficient to make the introduction of the new product profitable for the innovator. This element of the test for predatory product innovation requires the existence of a motive for predation. Clearly, there can be no motive for predation absent the structural conditions of horizontal concentration, entry hurdles, and reentry barriers. In addition, a finding that R\&D costs exceed the increment in net revenues earned under the viability premise does not establish a motive for predation if these costs also exceed the increment in net revenues with the rival's exit. Such a finding establishes only that the innovating firm overestimated the benefits it would obtain from its $R \& D$ investment.

As this last observation suggests, both the character and the details of the proposed test depend to a large extent on the significance of post-entry $\mathrm{R} \& \mathrm{D}$ costs. If these costs are small relative to the other incremental costs of the new product, then the test for predatory price reduction by a multiproduct firm is directly applicable. ${ }^{50}$ If post-entry $R \& D$ expenditures are

49. This issue arose in Transamerica Computer Co. v. IBM, 459 F. Supp. 626 (1978). The plaintiff (TCC) asked the court to consider the effects of a new product introduction on the profitability of preexisting product lines in calculating the cost-based price floor for ascertaining profit sacrifice. TCC urged that "impact cost," measured as "the reduction in anticipated future profits on an existing product line caused by the introduction of a new product line," should be subtracted from the new product's profit in "determining whether the price set was predatory and below cost." Id. at 630. The inclusion of impact costs was ruled to be impermissible as a matter of law on the ground that such inclusion would constitute a drawback to research and innovation and that impact costs are difficult to calculate. $I d$. at 631 .

This ruling is at variance with the economic analysis of tests for predatory profit sacrifice presented in this article. We argue that the introduction of a new product (or a price reduction on an existing product) can divert sales from preexisting products. The forgone profits from diverted sales should be netted out from the expected gross revenues that accrue to the firm from the introduction of a new product, or, equivalently, should be added to the incremental costs incurred for the product introduction. Absent an anticompetitive objective, a firm would not engage in the development and marketing of a new product if the new product were not expected to generate revenues sufficient to recoup its operating and fixed costs, including R\&D and marketing costs, and also to compensate the innovator for profits lost through sales diversion. As Judge Schnacke observed at trial, IBM had engaged in a very thorough financial analysis of the expected profitability of each of its new products. Transamerica Computer Co. v. IBM, 481 F. Supp. 965, 997-1002 (1979). Consequently, assessments of the impact costs were feasible. More importantly, however, impact costs would have been an important component of an economically sound test for predatory product innovations in the Transamerica litigation. The ruling to exclude such costs was inconsistent with our view that exit-inducing profit sacrifice for the sake of future monopoly gain is predatory.

50. See pp. 20-21 supra. 
significant, however, then the decision to undertake the R\&D investment must be tested for predation along with the innovator's pricing strategy.

When $R \& D$ costs are at issue, the purpose of the test is to determine the objective underlying the $R \& D$ investment decision. This determination requires scrutiny of the level of profits with and without the viability of the entrant and net of the post-entry $R \& D$ costs that are allocable to the innovation and were foreseeable at the time the investment was made.

As a defense to a charge of predation, the defendant may show that his inability to recover the full incremental cost of the newly introduced product, including the post-entry R\&D costs, stems from an exaggerated expectation of consumers' demand for the new product. ${ }^{51} \mathrm{~A}$ possible element of proof in this argument is a showing that the defendant attempted to recoup the initial outlay on $R \& D$. A high initial price, followed by price reductions to bolster sales, is indicative of such an attempt if supported by the appropriate marketing evidence.

The defendant's investment planning process may be the most useful source of data concerning the firm's expectations. Decisions to commit substantial funds to R\&D projects are likely to be supported by internal analyses of prospective costs and financial benefits. ${ }^{52}$ These analyses often identify the objectives of an $R \& D$ project, such as bringing a preconceived product to market, or generating basic research whose market applicability is as yet unknown. Because the costs of basic research cannot be attributed to specific products, such costs should be excluded from the tests for predatory sacrifice of profit. On the other hand, R\&D expeditures for preconceived products are relevant to the proposed tests of predatory sacrifice.

Of course, $R \& D$ projects are endemically subject to uncertainty both with regard to the cost necessary to achieve a given outcome, and the usable output achieved from a given outlay. This uncertainty exists for the firm at the time of its investment decision, as well as for factfinders seeking to determine the objective of that decision. The firm's objective is properly assessed in terms of the costs and benefits expected by the firm-which inform the firm's investment decision and which are reflected in the firm's internal analyses.

Once the relevant $R \& D$ expenditures are isolated, the proposed stan-

51. Of course, if the new product is truly unwanted by consumers, it is unlikely to cause the exit of a rival who produces a substitute product, and it is unlikely, therefore, that a charge of predatory innovation would ever be brought. Even an unsuccessful product, however, should be required to pass cost-based price tests that exclude considerations of post-entry R\&D costs; the mere fact that the product sells poorly should not preclude a charge of predatory conduct.

52. For example, the record in Berkey is replete with information about Kodak's R\&D investment decisions. See Berkey Photo, Inc. v. Eastman Kodak Co., 603 F.2d 263, 276-79 (2d Cir. 1979), cert. denied, 444 U.S. 1093 (1980). 
dard requires identification of the market conditions under which the innovator expects to recoup those expenditures. Market conditions play a central role in a firm's assessment of the expected benefits to be derived from $R \& D$. This assessment reflects the price that consumers are expected to be willing to pay for a new product, and the quantity that they are expected to purchase at a given price. These expectations must be based on knowledge of the array of substitute products available in the market and their prices. If an innovator's R\&D decision is actually based on an assessment of expected benefits that posits the continuing availability of rivals' products, then that decision is free of predatory sacrifice.

\section{The Dangers of "Off-the-Shelf" Product Innovations}

As shown above, whether a new product passes the proposed test for predation can depend significantly on the extent to which R\&D costs are included in the cost-based price floor. The proper allocation of these costs, however, depends upon when the allegedly predatory innovation was undertaken. If a new product is developed before entry occurs, and is introduced "off-the-shelf" after entry occurs, then the R\&D costs for the product were sunk prior to entry and should not be included in the cost-based floor. Otherwise, innovators would be accused of predation against rivals who did not exist at the time of the allegedly predatory conduct.

Concededly, this treatment of R\&D costs may give an innovator incentives to accumulate new product designs in anticipation of entry, ${ }^{53}$ and then to wait and introduce the designs after entry occurs. The magnitude of such incentives is generally small, however, because it is costly to withold product innovations from the market in anticipation of uncertain entry. First, the innovator must forego revenue from the sale of the new products until the time of entry. Second, the innovator must forego the return that would have been earned by investing the R\&D funds elsewhere. Third, there is a risk that actual or potential rivals may bring new products to market before the innovator, and thereby render the innovator's new product less profitable than it would have been if introduced earlier.

Moreover, innovating firms may have countervailing incentives to introduce products early to create artificial entry barriers. ${ }^{54}$ If incumbents fill the spectrum of products that match the diverse tastes of consumers, prospective entrants may find it difficult to create a new product that would

53. See Gilbert, Patents and Entry Deterrence, in STRATEgY, PREDATION, AND ANTITRUST ANALYSIS (S. Salop ed. 1981) (discussing entry deterrence through accumulation of unused product designs).

54. See Schmalensee, Entry Deterrence in the Ready-To-Eat Breakfast Cereal Industry, 9 BELL J. ECON. 305 (1978) (arguing that brand proliferation, product differentiation, and intensive advertising create barriers to entry). 
make entry profitable. Thus, according to the entry-deterrence theory of product competition, incumbent firms may offer an excessive, socially inefficient variety of products to prevent the entry of new rivals. ${ }^{55}$ In view of this countervailing incentive, and in view of the other costs of witholding innovations from the market, the incentives for over-accumulation of product designs are probably small.

To further reduce these incentives, plaintiffs might be permitted to introduce evidence of off-the-shelf innovation as proof of predation. The plaintiff might argue that the exit-inducing aspect of the product introduction made the introduction profitable, even though it was unprofitable prior to the plaintiff's entry. If so, the product introduction entailed a sacrifice of profit under the continued viability premise.

Despite the strength of this argument, however, off-the-shelf product introductions in response to entry are not necessarily predatory. The change in market structure due to entry can have a number of effects on the profitability of a product introduction. For instance, the introduction may be more profitable post-entry than pre-entry because with more products in the market, the new product diverts fewer sales from the innovator's own substitute products. In some instances, therefore, off-the-shelf product introductions may be part of socially desirable product competition. Consequently, it would be socially counterproductive to place undue weight on the fact that a product introduction is taken off-the-shelf. Rather, off-the-shelf innovation should be treated like other innovation. The R\&D costs to be tested for predation should be limited to those incurred after the innovator became aware of the rival's actual or impending entry. The plaintiff may utilize the fact that the innovator found the product introduction unprofitable prior to entry, however, to bolster the showing of predatory profit sacrifice.

\section{Summary}

Because technological progress is desirable and should not be stifled by the antitrust laws, it may be tempting to follow the view that if engineering data suggest that a new product is superior to the product it replaces, antitrust inquiry should end. ${ }^{56}$ Such products, however, do not always generate higher social welfare. ${ }^{57}$ Under the proposed standard, the rele-

55. Entry-deterrence theory and its relevance to antitrust policy is criticized in Easterbrook, supra note 7, at 282-97. But see Williamson, Antitrust Enforcement: Where It's Been; Where It's Going (University of Pennsylvania Working Paper, May 1981) (on file with Yale Law Journal) (concluding that entry deterrence theory is useful to antitrust analysis).

56. See ILC Peripherals Leasing Corp. v. IBM, 458 F. Supp. 423, 439 (N.D. Cal. 1978), affd sub nom. Memorex Corp. v. IBM, 636 F.2d 1188 (9th Cir. 1980).

57. We have argued that a profitable new product may not be socially beneficial if its $R \& D$ costs can be defrayed only by the additional monopoly profit attendant on the exit of rivals. Other authors 
vant question is whether the innovator anticipated positive incremental profit for the new product, given the continued viability of the rival. The incremental profit measure should be calculated net of the losses resulting from diversions of sales from the innovator's preexisting products, and net of all post-entry $R \& D$ costs. If the post-entry $R \& D$ costs are small because the new product was introduced "off-the-shelf," the plaintiff may attempt to show anticompetitive conduct from the fact that the off-theshelf design was introduced only in response to entry.

\section{B. Predatory Systems Rivalry}

Most of the recent cases pertaining to predatory product innovations deal with the phenomenon of systems rivalry. ${ }^{58}$ Typically, the defendant was a firm that had been offering systems components that were compatible with the components produced by a rival, as well as systems components that were competitive with the components produced by the rival. The defendant then introduced a new system of components that were incompatible with those of the rival, thereby threatening the rival's viability.

To illustrate, consider a market for widget systems in which consumers derive utility from appropriate combinations of widgets and widget accessories. The dominant manufacturer of widgets, firm A, also manufactures widget accessories, as does a rival firm, firm B. At some point in time, however, firm A introduces a new line of widgets and compatible accessories that threatens the viability of firm $B$ because the new widgets are incompatible with firm B's accessories. If firm A's new widget system is sufficiently superior to the old widget system in the perceptions of consumers, firm B may be driven out of the widget systems market even if the price of the old systems remains the same. Firm A can increase the likelihood of firm B's exit, however, by increasing the price of the old-style widgets or by discontinuing their production.

This section provides workable tests to determine whether the introduc-

have shown that a profitable new product may lower sacial welfare if it diverts demand from substitute products that are produced with significant economies of scale. See, e.g., E. CHAMBERLIN, THE THEORY OF MONOPOLISTIC COMPETITION (6th ed. 1948); R. WILLIG, WELFARE ANALYSIS OF POLICIES AFFECTING PRICES AND PRODUCTS (1979); Dixit \& Stiglitz, Monopolistic Competition and Optimum Product Diversity, 67 AM. ECON. REV. 297 (1977); Spence, Product Selection, Fixed Costs, and Monopolistic Competition, 43 REV. ECON. STUD. 217 (1976).

58. California Computer Prods., Inc. v. IBM, 613 F.2d 727 (9th Cir. 1979); Telex Corp. v. IBM, 510 F.2d 894 (10th Cir. 1975), cert. dismissed, 423 U.S. 802 (1975); Transamerica Computer Co. v. IBM, 459 F. Supp. 626 (N.D. Cal. 1978), 481 F. Supp. 965 (N.D. Cal. 1979), appeal docketed, No. 80-4048 (9th Cir. Jan. 31, 1980). See also Berkey Photo, Inc. v. Eastman Kodak, Co., 603 F.2d 263 (2d Cir. 1979), cert. denied 444 U.S. 1093 (1980); MCI Communications Corp. v. AT\&T, 969 ANTITRUST \& TRADE REG. REP. (BNA) A-3 (N.D. Ill. June 19, 1980), appeal docketed, No. 80 2171 (7th Cir. Aug. 27, 1980); ILG Peripherals Leasing Corp. v. IBM, 458 F. Supp. 423 (N.D. Cal. 1978), aff'd sub nom. Memorex Corp. v. IBM, 636 F.2d 1188 (9th Cir. 1980). 
tion of a new system into an existing systems market, coupled with price adjustments on components of the old system, is anticompetitive. Under the proposed general standard of predation, a finding of predatory conduct requires both a showing of motive and a showing of profit sacrifice. There is no clear motive for predatory systems rivalry if the dominant firm can earn all of the monopoly profits obtainable in the market by charging an elevated price for the component of the system over which the dominant firm already possesses monopoly power. Monopoly power over one component of a system, however, is not always sufficient for a dominant firm to extract all the monopoly profits obtainable in the systems market. In such instances, the dominant firm can increase its profit by inducing the exit of a rival and thereby extending its monopoly power to other systems components. ${ }^{59}$ We argue that the conditions necessary for this incentive for predation are the rule rather than the exception, and hence that courts should presume their existence. Of course, a motive for predation also requires that the systems market is concentrated and protected by entry hurdles and reentry barriers.

Once the existence of a motive is established, the test for profit sacrifice proceeds in two stages. The first stage requires an examination of the post-innovation prices of the components that are compatible with the products of the rival. The innovator's behavior is free of profit sacrifice only if he offers to provide his rivals with the necessary compatible components at compensatory prices, in preference to making far fewer sales at higher prices or to making the components unavailable. The prices of old components are compensatory if they cover the cost of supplying the old component and yield the same incremental profit as the displaced crosselastic sales of new and other components, assuming the rival remains viable in the systems market. Gompensatory prices of old components should not reflect the additional monopoly profits that the innovator would earn if a rival were irreversibly driven out of the market.

The second stage of the test for profit sacrifice examines the rationality of the R\&D investment in the new system, under the assumption that the

59. Other writers contend that a firm has no incentive to "lever" its market power from one market to another. Under this theory, the nature of vertical relations between firms is entirely determined by efficiency considerations. See R. POSNER, ANTITRUST LAW: AN ECONOMIC PERSPECTIVE 173-74 (1976) (weakness of leverage theory is inability to explain why firm with monopoly over one product would want to monopolize complementary products); Easterbrook, supra note 5, at 308 (concluding that dominant firm cannot lever its market power through innovations since attempts at leverage impose costs on purchasers of goods). But see Ordover \& Willig, Notes on Non-price Anticompetitive Practices by Dominant Firms (unpublished paper prepared for the 9th Annual Telecommunications Policy Research Conference, April 27-30, 1981) (on file with Yale Law Journal). The Berkey case holds, however, that a new system can be predatory if it would enable a firm with monopoly power to lever this power into competitive advantage in another market. Berkey Photo, Inc. v. Eastman Kodak Co., 603 F. 2d 263, 275-76, 285-88 (2d Cir. 1979), cert. denied, 444 U.S. 1093 (1980). 
innovator offers the old components at compensatory prices. This stage of the test, therefore, is conceptually equivalent to the tests developed in section III A that dealt with the introduction of substitute products.

\section{Basic Concepts in Systems Rivalry}

A "system" is a collection or package of complementary products that are combined by a manufacturer, or a consumer, to yield a final product. Because the components of the system are complementary products, an increase in the price of one component reduces the demand for the other components. ${ }^{60}$

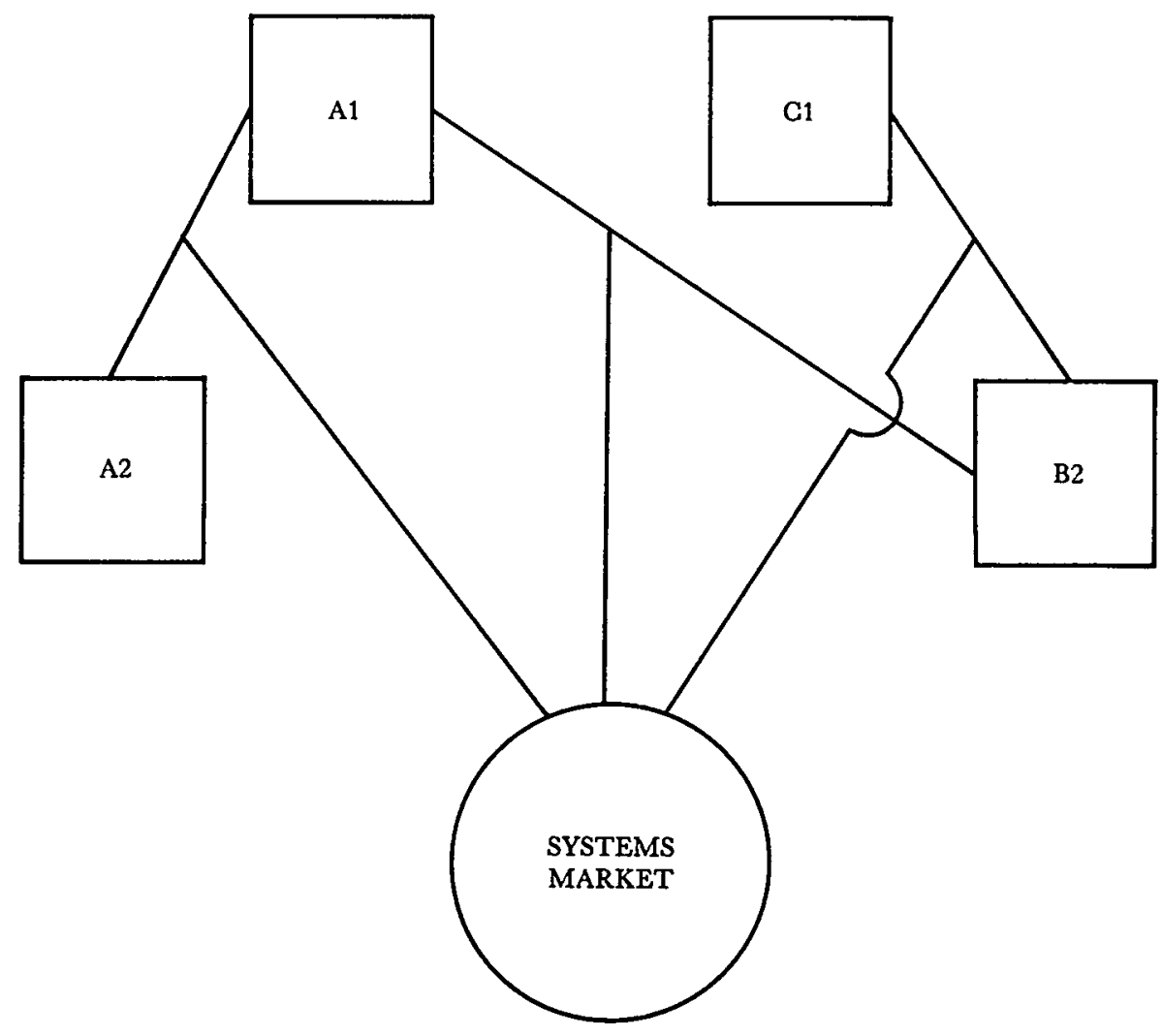

Figure 1

Frequently, a system can be assembled from complementary compo-

60. For example, an increase in camera prices tends to reduce the demand for film, and an increase in prices of computer central processing units tends to reduce the demand for the associated peripheral equipment. 
nents that are produced by different manufacturers, as long as the various components are "compatible" with each other-that is, as long as the components of various manufacturers are interchangeable without much loss in their efficiency. If the components of various manufacturers are compatible, then competition in the systems market is enhanced. Concomitantly, incompatibilities reduce competition, and the creation of incompatibilities may increase the monopoly profits of a firm that has monopoly power over one or more of the components.

Figure 1 diagrammatically summarizes the basic elements of systems rivalry. Each system consists of two complementary components, denoted by the numbers 1 and 2 . The three manufacturers are denoted by the letters A, B, and C. Thus, A1 stands for the first component manufactured by firm $A$, and $B 2$ stands for the second component manufacturered by firm B. A line joining two components indicates that the two components are compatible. The absence of a line indicates incompatibility. Thus, in Figure 1, A1 and B2 are compatible, but $\mathrm{C} 1$ and A2 are not compatible. There is substantial intersystem rivalry in the final systems market, because consumers can select from three distinct systems, all of which may be perfect substitutes for each other.

In Figure 2, however, firm $\mathrm{A}$ has a monopoly over the first component, A1, and also produces a compatible second component, A2. Firm B specializes in the production of the second component, which is compatible with A1. In this market scenario, two business decisions by firm A may disadvantage the rival firm $B$, whatever firm A's underlying motive, and irrespective of the effects of its decisions on competition. First, firm A can refuse to deal ${ }^{61}$ with firm $\mathrm{B}$ by withholding the complementary component from the open market and selling it exclusively as a part of a system. ${ }^{62}$ Second, firm A may engage in the related tactic of price discrimination. A price discriminating firm sets two prices-a high price on components that are sold to a rival or its customers, and a low price on components that are sold to customers who do not purchase components from a rival. The extreme form of this strategem is a price that chokes off all effective demand for separate sales of the relevant component; such a price has the same effect on the rival as a pure refusal to deal.

61. See generally Note, Refusals to Deal by Vertically Integrated Monopolists, 87 HaRV. L. REv. 1720 (1974).

62. In Figure 1, the refusal to deal by firm A may have little impact on the ability of firm $B$ to compete with firm $A$, because firm $C$ is an alternative source for the complementary component. Specifically, the impact of firm A's decision is minimized if component $\mathrm{C} 1$ is a good substitute for Al in the opinion of consumers; component $\mathrm{B} 2$ can casily be made compatible with component $\mathrm{C1}$; and manufacturer $\mathrm{C}$ does not increase the price of $\mathrm{C1}$ after the refusal to deal by firm A. In Figure 2, however, firm $A$ is the only source of component 1 , and a refusal to deal may drive firm $B$ out of the market unless a new entrant into the market commences production of component 1. 


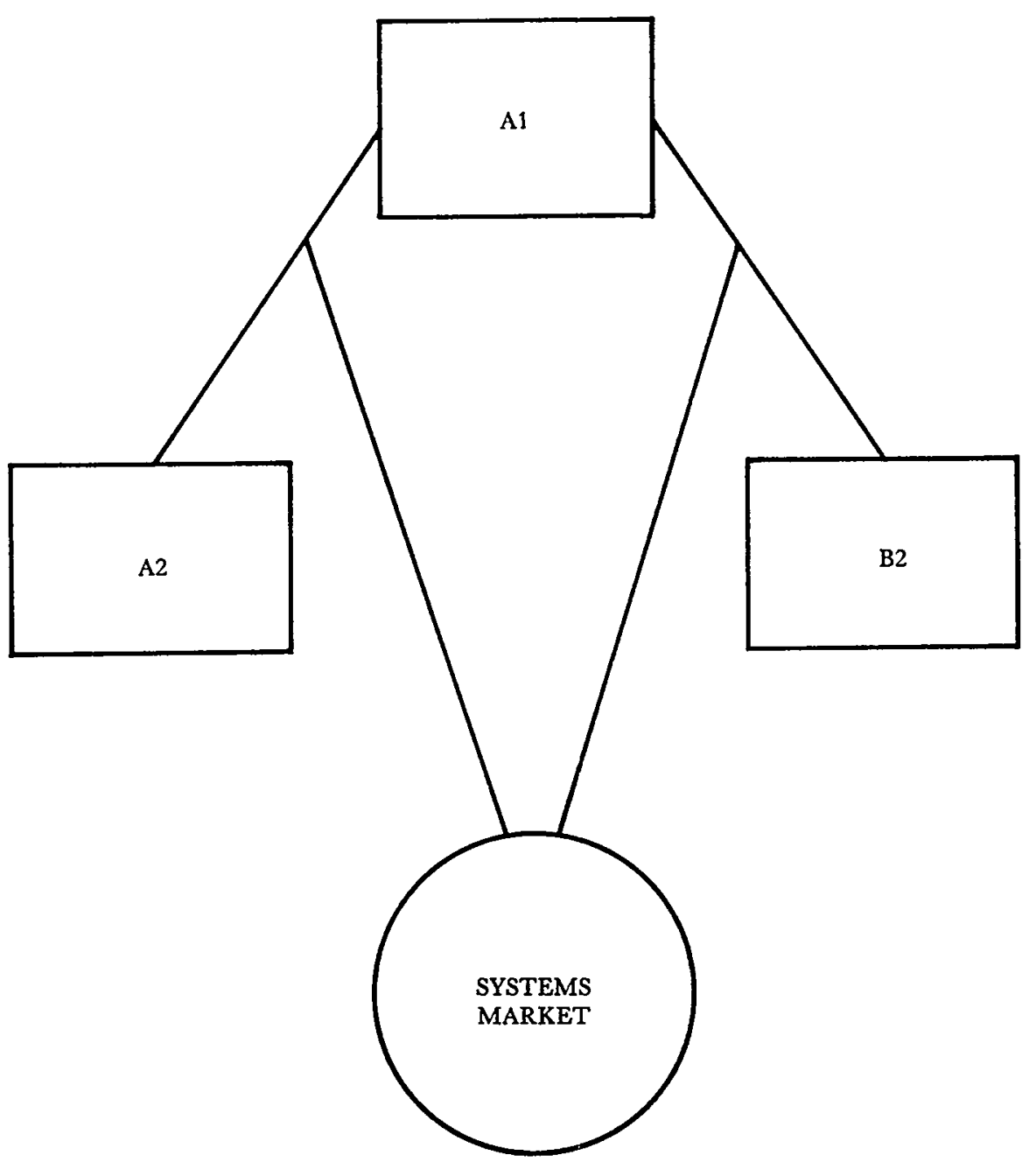

Figure 2

Refusal to deal and price discrimination may be procompetitive regardless of their effects on rivals. Both practices would be procompetitive, for example, if they were necessary to maintain the system's reputation for quality, the product differentiation of the system, ${ }^{63}$ or the supply of requi-

63. In the presence of product differentiation, consumers have the opportunity to choose among the various aspects of product design for which tastes and needs may differ. Other things being equal, therefore, product differentiation benefits consumers. Moreover, product differentiation may promote competition. For example, product differentiation may be essential to new entrants who cannot compete with existing firms merely by mimicking their products. By assembling a system that is distinct from those of their rivals, entrants may avoid head-on price competition, at least until after they can establish themselves in the market. If firms are compelled to sell the unique components of their 
site system components.

In other instances, however, the two strategies may be anticompetitive, and transparently without a business justification other than the pursuit of monopoly power. To avoid the appearance of anticompetitive intent, a firm may employ a less obviously anticompetitive strategy that still permits the extension of its monopoly power over one component into monopoly power over the entire systems market. The introduction of new systems can be a camouflaged anticompetitive strategy, precisely because the introduction of new products or systems is typically regarded as procompetitive and beneficial to consumer welfare. ${ }^{64}$

The introduction of a new system can disadvantage rivals in at least two ways. First, if the new system is superior to existing systems, demand for the existing systems will decline. Second, the innovator may constrict the supply ${ }^{65}$ of the components that are compatible with those of the rival by increasing the prices of preexisting components, or discontinuing their production. Discontinuance of the old components is particularly damaging to the rival's profits; the more incompatible the rival's components are with the new components, the more costly it is for the rival to introduce components that are compatible with the innovator's new components, and the more costly or inferior are the substitute components available from other producers in the market. Although these injuries to rivals may be incidental to socially beneficial product innovation, they are the primary motivation for predatory product innovations.

If the innovating dominant firm continues to supply the old components at compensatory prices, the introduction of the new system can be tested for predation using the tests developed in Section III A. Distinct issues arise, however, if the defendant increases the prices of existing components above their compensatory level; because the potentially predatory conduct does not involve a price cut, but rather a price increase, the standard comparison between prices and costs is inappropriate.

systems to rivals, however, product differentiation may not be feasible. See U.S. v. Columbia Pictures Indus., Inc., 507 F. Supp. 412 (S.D.N.Y. 1980).

64. See Berkey Photo Inc. v. Eastman Kodak Co., 603 F.2d 263, 287 (2d Cir. 1979)(concluding that market acceptance of innovation is best indicator of product quality and of benefit to public as long as market permits free choice of consumers); ILG Peripherals Leasing Corp. v. IBM, 458 F. Supp. 423, 439 (N.D. Cal. 1978), aff'd sub nom. Memorex Corp. v. IBM, 636 F.2d 1188 (9th Cir. 1980) (same, with proviso that consumer's choices have not been manipulated by the monopolist); Comment, Antitrust Scrutiny of Monopolists' Innovations: Berkey Photo Inc. v. Eastman Kodak Co., 93 HARV. L. REV. 408, 414-15 n.60 (1979) (concurring with view expressed in Berkey).

65. In general, an innovator can constrict the supply of compatible components in several ways: refusing to deal with the rival; selling the components only as a complete system; pricing the components in a way that discriminates against rivals; selling the components as a complete system in combination with high individual prices for the compatible components if sold separately; underpricing components that compete with the components of rivals; overpricing components that are compatible with the components of rivals; or, as suggested in the text, introducing a new system that is incompatible with rivals' products while overpricing or withdrawing the necessary preexisting components. 
Nonetheless, the proposed general standard of predatory behavior yields workable tests for predatory systems rivalry. For conduct involving the introduction of a new system and an attendant price revision to be predatory, the dominant firm must have a motive for inducing the exit of a rival, the challenged conduct must substantially increase the probability that the rival will exit, and the conduct must entail a profit sacrifice in comparison to the profits that could be earned, with the continued viability of the rival, if the innovator pursued an alternative strategy.

\section{Motives for Predation: The Economics of Vertical Price Squeezes}

When a firm has monopoly power over one component in a system, conventional economic wisdom suggests that the firm can extract all the monopoly profit available in the systems market by charging a sufficiently high price for the monopolized component-that is, by executing a vertical price squeeze. If that is true, why should the firm bother to engage in predation against a rival manufacturer of a complementary component? The answer to this question is critical to the understanding of the profit motive for tactical exit inducement in the systems' context, and also to the construction of tests for predatory profit sacrifice.

Consider a market scenario in which a firm with market power has no motive to induce the exit of its rival. In Figure 3, the dominant firm can extract all the monopoly profit that is available in the systems market by subjecting the rival to a carefully designed vertical price squeeze. The unit incremental cost of the first component is equal to $c$, and the unit incremental cost of the second component is equal to a, regardless of who produces it. Assume that all consumers are identical and have a maximum willingness to pay of $b$ for either system. If the system price is $b$ or less, each consumer will buy one system. If the price exceeds $b$, consumers will not buy any systems.

In this scenario, the viability of firm $B$ need not diminish the monopoly profits of firm A. ${ }^{66}$ To see this, consider the profits that firm A can earn in the absence of firm B, and then consider the profits that firm A can earn with a perfect price squeeze against a viable firm $B$.

In the absence of firm $B$, firm $A$ will maximize its profit by selling systems to consumers at the highest possible price-their willingness to pay of $b$. Since each system costs $c+a$ to produce, each sale yields a profit margin of $b-(c+a)$. Firm A's total profit is equal to $b-(c+a)$ multiplied by the number of sales in the entire systems market.

66. In fact, if the rival is a more efficient producer of component two, then the profits of firm A are larger if firm B remains viable. See note 67 infra. 


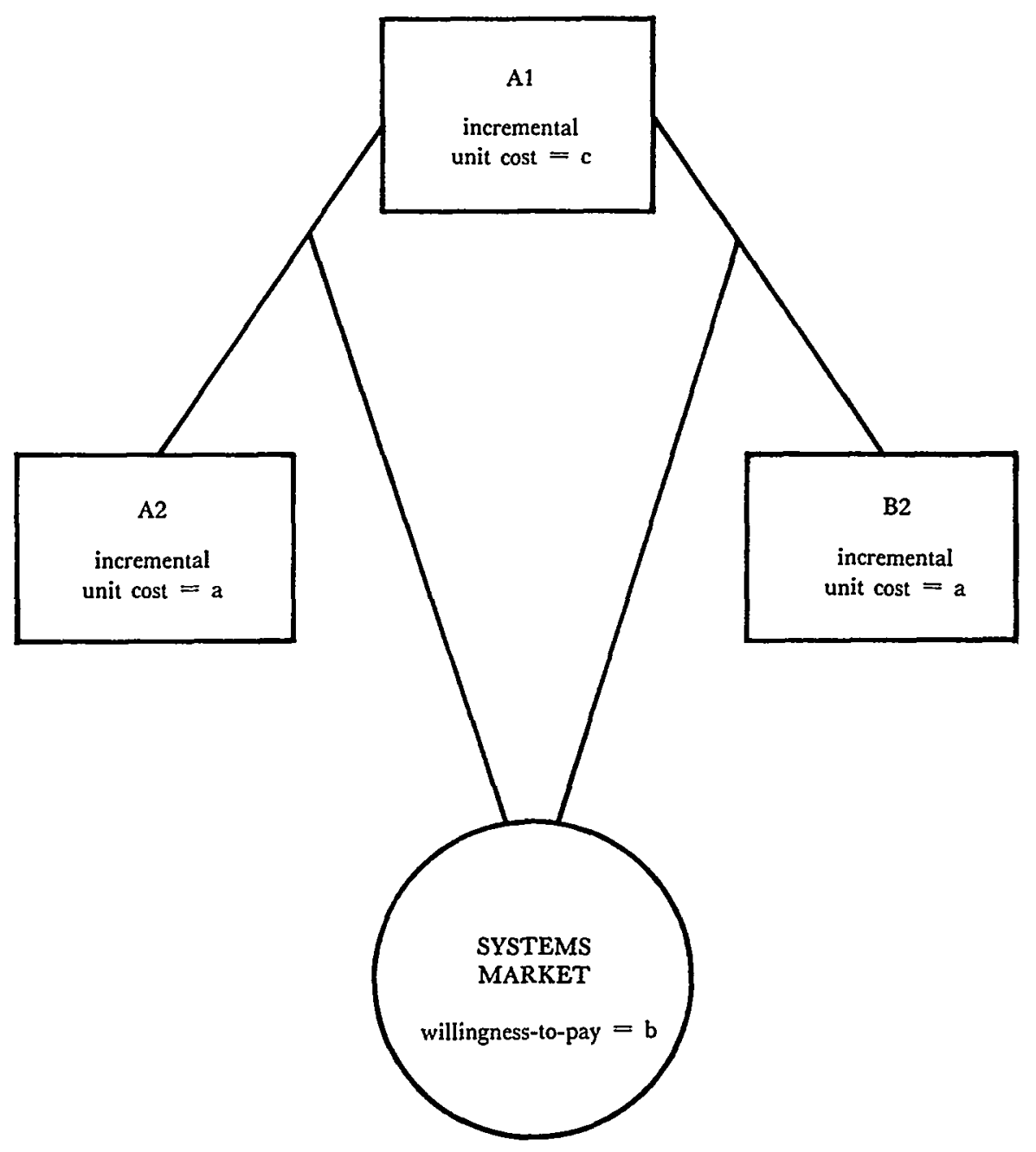

Figure 3

Now suppose that firm $B$ is a viable competitor of firm $A$. The presence of firm B constrains the equilibrium price of type-two components to a, their unit cost. Nonetheless, firm A can extend its monopoly power over type-one components to the entire systems market by charging a price of $b$ for entire systems, a price of $b-a$ in the open market for type-one components, and a price of $a$ in the open market for type-two components. Then, a direct sale of a whole system by firm $A$ has $b-(c+a)$ as its profit margin. A system that is comprised of components $A 1$ and $B 2$ yields to firm A a profit of (b-a)-c, through its sale of component $A 1$ at the price of (b-a) and with the cost of $c$. Finally, a system assembled by consumers 
that is comprised of components $A 1$ and $A 2$ yields to firm A a profit of (ba)-c on its sale of $A 1$ and no profit on its sale of $A 2$ at cost. Thus, with a perfect price squeeze, firm $A$ does not lose profits if consumers choose systems that include the rival's component rather than systems that are wholly comprised of firm A's own components, ${ }^{67}$ and firm $A$ has no incentive to extend its monopoly power to the second component.

Such a perfect price squeeze, however, requires that all of the profits available in the systems market be captured through the markup on the monopolized component. One impediment to the execution of such a price squeeze may arise when system components can be utilized in different mixes by different consumers. For example, consumers who demand relatively more of the non-monopolized components for their systems may have a more than proportionately greater willingness-to-pay for systems. Then, only prices that embody a relatively high markup on the non-monopolized component and a relatively low markup on the monopolized component can transfer to suppliers the willingness-to-pay of these consumers along with the smaller willingness-to-pay of other consumers. Such prices constitute a form of price discrimination in the systems market between the different groups of consumers. They are infeasible in the presence of competition in the sale of the non-monopolized component, however, and are inconsistent with the use of a price squeeze. Thus, if this type of price discrimination is necessary for a monopolist to derive maximum profits from the systems market, a firm with monopoly power over one component has incentives to extend its power to other components.

The desire to price discriminate, however, is not the only obstacle to the implementation of a price squeeze. Regulated firms, for example, may be unable to charge the unbalanced markups needed to implement a perfect price squeeze. Alternatively, consumers may underestimate their demand for the components subject to competition and this circumstance may enlarge the profit-maximizing markup on those components. In addition, consumer uncertainty about the value of a given system may call for promotional pricing of the very component that must carry a high markup in a price squeeze.

The most important type of impediment to the use of a price squeeze, however, is the existence of an alternative source of supply of the monopo-

67. If firm B can produce type two components at a lower cost than firm A, say $a^{\circ}$, firm A can extract the maximum profits available in the systems market only if firm $B$ remains viable. The profit maximizing tactic for firm $A$ is to set a price for $A 1$ of $b-a^{\circ}$, and a price for the entire system just above $b$. Then, firm B cannot price B2 above $a^{\prime}$, because a higher price would raise the total cost of a system above consumers' willingness to pay. Hence, firm A would not sell any units of A2, and would earn a profit of $b-a^{\prime}-c$ on each sale of $A 1$. This is the maximum profit available in the systems market, and it exceeds b-a-c, which is the maximum profit in the absence of firm $B$. 


\section{Predatory Product Innovation}

lized component, which is of inferior quality or which incurs a higher cost of production, but which limits the markup that the market will bear on the monopolized component. Figure 4 depicts a market scenario in which the monopoly power of the dominant firm is limited by an inferior source of supply. ${ }^{68}$ There are now three firms in the market: the dominant firm $A$, which manufactures both system components, and the specialized firms, B and C, which manufacture only one component. Assume that the dominant firm has a relatively small cost advantage over the other manufacturer of the first component, equal to $d$.

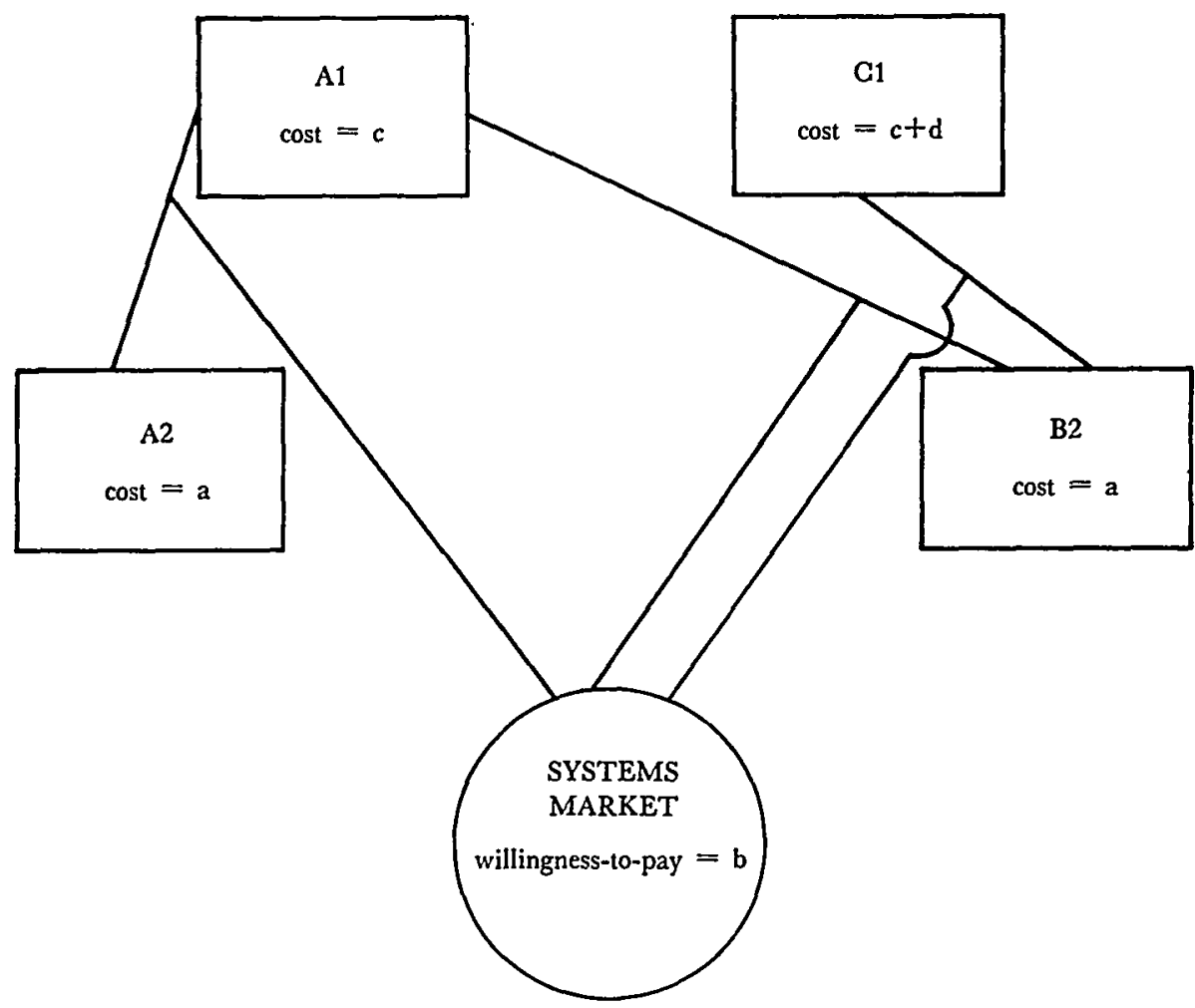

Figure 4

Absent the rival manufacturer of the second component, firm B, firm A's small cost advantage over firm $C$ could be levered into substantial monopoly profits. Firm A could set the system price at $b$ and earn the maximum profit of $b-(a+c)$ on each system sold. ${ }^{69}$ With firm $B$ in the market, however, the competing perfect substitute system of C1 and B2

68. The model in the text applies whether the inferior source of supply is an actual or a potential rival of the dominant firm $A$.

69. See pp. 36-37 supra. 
can be sold for a total price of a $+c+d$, and this amount is then the maximum that firm A can charge for a system. At that price, the profit margin for firm A is only $d$. Of course, in the absence of both of the competing firms B and $C$, firm A could earn $b-(a+c)$ on each system-the full monopoly profit available in the systems market.

In some instances, the most effective way for firm A to earn the full monopoly profit is to drive firm $\mathrm{C}$ out of the market. In particular, a nonpredatory price of $c$ for component A1 would divert all sales of component one from firm $C$ to firm $A$, and might thereby induce firm C's exit. The viability of firm $\mathrm{C}$, however, may not rest on events in the market in question. Instead, component $\mathrm{C} 1$ may have alternative uses for which $\mathrm{A} 1$ does not suffice. Thus, firm $C$ might survive despite the postulated cost advantage of component $\mathrm{A} 1$ over component $\mathrm{C} 1$ in this market. ${ }^{70}$ Alternatively, firm $\mathbf{C}$ may face very low reentry barriers. Under such circumstances, only the exit of firm B will enable firm A to capture the full monopoly profit available in the systems market, ${ }^{71}$ and the existence of an inferior source of supply provides the dominant firm with a motive for tactical exit inducement.

In applying the proposed test for predation, courts should not require a detailed, dispositive showing of alternative though inferior sources of supply, because such sources of supply are common in actual systems markets. $^{72}$ To satisfy the motive element of the test for predation, however, a

70. Firm $\mathrm{G}$ can survive in the long-run either because its product has purposes for which component $A 1$ is ill-suited or because its productive capacity has other uses. Of course, if the viability of firm $\mathrm{C}$ depends upon sales of $\mathrm{C} 1$ in the market with $\mathrm{A} 1$, it cannot withstand competition from firm $\mathrm{A}$, and it will exit the market. Because of the other uses for firm C's products or capacity, however, it remains a potential competitor, and constrains the market power of firm A as long as firm B remains viable.

71. In this scenario, the most direct way for firm $A$ to induce the exit of firm $B$ involves a refusal to deal and a low systems price: firm $A$ refuses to sell the first component in the open market, and prices its complete system just below a $+c+d$. At this price, consumers will not demand systems assembled from components $\mathbf{C} 1$ and B2 unless firms B or $\mathbf{C}$ are willing to sell their components below cost.

If the dominant firm cannot refuse to deal with firm $B$, however, it may still induce the exit of firm $B$ by selling the second component below cost. For example, firm A can sell the first component for $c+d$, and price the second component below a, its incremental unit cost. This tactic obviously violates the Areeda-Turner test, as well as the cost-based price floors proposed in this article. See pp. 15-19 supra.

Alternatively, firm A may induce the exit of firm B by charging in the open market a discriminatory price for A1 that is slightly below $c+d$, while setting a lower internal transfer price for $A 1$ and an internal price for $A 2$ equal to a. In so doing, firm $A$ can sell a complete system in the market for less than consumers must pay for a system comprised of $A 1$ and $B 2$. The unit production cost of A2 provides a "conservative" estimate for the imputed internal price of A2 because it results in a larger estimate of the imputed price for A1 than would any other figure not below the cost of A2. Then, if this estimate of the imputed price for A1 is smaller than the actual price charged for A1 in the open market, the latter price is discriminatory and has the effect of excluding firm B from the market to the advantage of firm $A$.

72. There is an alternative source of supply if the rival's components can be utilized in the systems market with components other than those supplied by the defendant firm. These alternatives may be newly developed products, or newly modified versions of products with other uses. All that is 
demonstration of other structural conditions in the system market remains necessary. First, the defendant must possess monopoly power over some of the components of the system. Second, entry hurdles into the overall systems market must exist. Third, if there are alternative, inferior sources of supply of the components over which the defendant exercises monopoly power, there must be entry hurdles and reentry barriers into the production of the other components needed to complete a system. Finally, if implicit price discrimination would be profitable, entry hurdles and reentry barriers into the supply of components that would undermine implicit price discrimination must exist. The existence of all of these structural conditions may create a motive for predatory exit inducement.

\section{Predatory Systems Rivalry, Compensatory Pricing of Complementary Components, and the Analysis of Research and Development Investments}

The introduction of a new system is predatory only if it entails a sacrifice of profit given the continued viability of the rival. ${ }^{73}$ Because competition in the systems market as a whole protects the interests of consumers, the relevant market for the definition of a rival's viability is the final systems market. ${ }^{74}$ Consequently, the continued viability premise implies more than an absence of reentry barriers; even if the productive assets of the rival remain available for production, the rival is not viable in the systems market if compatible components are unavailable. ${ }^{75}$ The absence of com-

necessary is that some alternative system would become economical if the dominant firm attempted to raise the prices on its preexisting component to the point where they would extract the total monopoly profit from the systems market. Hence, the alternative will not always be identifiable by the uses to which it is presently put, because the dominant firm will have incentives to maintain its prices below the point at which it becomes economical. For example, in Telex, the court noted that Telex's peripherals could be made compatible with Burroughs' CPU's, even though this was not the economic choice in view of the pricing policy of IBM. Telex Corp. v. IBM, 510 F.2d 894, 916 (10th Cir. 1975), cert. dismissed, 423 U.S. 802 (1975).

73. See note 75 infra (meaning of viability in context of systems rivalry).

74. Concededly, the systems market is not always the relevant market. For example, after a durable product is purchased by consumers, there may be a distinct market for replacement parts or for accessories compatible with the product. For consumers who are not locked-in to a particular system, however, the systems market is the appropriate market for antitrust scrutiny.

Similarly, if consumers underestimate their need for a system component, they will place too little weight on its price in choosing which system to purchase. Hence, in addition to competition in the systems market, competition in the supply of that component is necessary. With correctly informed consumers, however, the relevant market again is the systems market.

75. One could define viability narrowly in terms of the rival's ability to offer components that are compatible with the new system, rather than in terms of the rival's ability to compete in the systems market. This pro-rival conception of viability, however, suffers from irresolvable difficulties. In many instances, the rival's preexisting components may be technologically incompatible with the new system, and the narrower definition of viability would imply that the rival has access to the innovative designs embodied in the new system. Such access could unduly constrict the temporary quasi-monopoly profits available to the innovator, however, and thereby chill socially beneficial innovation. That is, for an innovating firm to recoup its initial outlay on $R \& D$, it must be assured some respite from 
patible components implies that: the defendant refuses to sell the components at compensatory prices; there are no existing alternative suppliers of compatible components; there are barriers that prevent the entry of an alternative supplier; and the rival is unable to produce, quickly and at sufficiently low cost, components that are compatible with the new system.

Profit sacrifice is present if there exists an alternative action, less damaging to the rival, that yields to the incumbent a higher level of profit under the continued viability premise. If the rival is a manufacturer of complementary products, the less damaging alternative action involves prices that are lower than the actual prices of the necessary complementary components. The repricing or withdrawal policy of the innovator exhibits profit sacrifice if a lower price is feasible ${ }^{76}$ and yields no less profit on the premise of the continued viability of the rival.

A lower price on the preexisting component has four distinct effects on the profits of the innovator. First, it increases profit by the markups on the additional sales of the preexisting component, and by the markups on the innovator's additional sales of complementary products. Second, it reduces profit from sales of the preexisting component that would have been made at the higher price. Third, it reduces profit by the markups on the diverted sales of the new components. Fourth, because a lower price on the preexisting component is less likely to induce the rival's exit, it reduces the future profits of the innovator by diminishing his future monopoly power (if any) in the systems market.

This fourth effect may provide a motive to induce exit by the introduction of new components and the repricing of old components. This effect on profit, however, is eliminated under the premise of the continued viability of the rival in the systems market. ${ }^{77}$ Thus, the test for predatory profit sacrifice should disregard profits that are only possible as a result of the actual exclusion of the rival. ${ }^{78}$

imitation-an "imitation lag." If the imitation lag shrinks to zero, rivals can generally undersell the
innovator and still make a positive incremental profit because their expenditures on imitative R\&D
are generally lower than the R\&D expenditures of the innovator. To cope with this problem, a court
would have to determine the socially optimal duration of the imitation lag for each new system, and
would have to decide whether the innovating firm has unduly lengthened the imitation lag. Such
findings would inevitably contain substantial errors; prospective innovators might reduce their invest-
ments in R\&D in fear of such errors, thereby stifling the innovative process.
76 . If the costs of providing the preexisting components are prohibitive, the compensatory price
will be prohibitive. This may occur if the production of the old components renders the production of
the new components physically impossible, or vice-versa.
77. In making the profit assessment, data that pertain to the period following the introduction of
the innovation but preceding the actual exclusion of the rival are the most useful. When the attribu-
tion of incremental profits to various components is ambiguous due to data limitations, conservative
methods should be chosen so as to bias the scrutiny of profit sacrifice in favor of the innovator. A
useful rule of thumb may be to exclude from consideration any loss of profits on the part of the
innovator from new line components that substitute for the rival's components.
78 . Similar analysis applies in the context of predatory pricing. For example, a price below cost 


\section{a. Compensatory Prices}

The compensatory price for a preexisting component is the lowest price that would compensate the innovator for making the component available, under the continued viability premise. Thus, an innovator who substantially damages rivals by refusing to sell preexisting components, rather than selling them at compensatory prices, is sacrificing profit under the proposed standard. Although the innovator may set a price above the compensatory level if such a price yields an even higher profit contingent on the rival's viability, prices higher than the compensatory level may entail predatory profit sacrifice.

For example, if sales of the old component divert sales of the new component on a one-to-one basis, and if sales of the old component have no other effects on the innovator's profits, then the compensatory price contains a markup over cost exactly equal to the markup over cost on the new-line component. In this simple case, the one-to-one diversion of sales occurs if the price differential between a system comprised of new components and a system comprised of old components exceeds consumers' evaluation of the quality differential between the two systems. Predatory profit sacrifice is present if the rival must exit because the incumbent sets a price above the compensatory level, and if the rival or its customers would purchase the preexisting component at a lower but supra-compensatory price. By the definition of a compensatory price, a lower price above the compensatory level would increase the profits of the innovator under the continued viability premise, because the markup on the additional sales of the preexisting component would exceed the markup on the diverted sales of the new-line component. ${ }^{79}$

The following model of a market with an inferior source of supply ${ }^{80}$ illustrates the calculation of the compensatory price under these assumptions. Figure 5 provides the structure of this hypothetical market. The symbols $A 1^{\prime}$ and A2' denote the components of the new system introduced by the dominant firm $A$. The associated unit costs are $c^{\prime}$ and $a^{\prime}$, and con-

may be defended as a promotional device. Cf. M. PORTER, INTERBRAND ChOICE, STRATEgY AND BILATERAL MARKET POWER (1976) (extensive up-to-date discussion of promotional strategies). If future sales are complementary to current sales, a low or even negative markup on current sales may be justified by higher future revenues. When complementarity exists, however, the future markups used to assess profit sacrifice should reflect the assumed viability of the rival; otherwise, predation would be logically impossible.

79. If the diversion of sales is not one-to-one, or the sales of the old component have other effects on the innovator's profits, then the equal markup rule for compensatory pricing must be modified. For example, if the sale of one preexisting component diverts the sale of more than one new-line component, the compensatory markup must equal the sum of the markups on those diverted sales. In general, the compensatory price must reflect all three of the effects that the post-innovation price of oldline components has on the innovator's profits under the continued viability premise. See p. 42 supra.

80. See pp. 38-41 supra. 
sumers' willingness-to-pay for the new system is $b^{\prime}$. As indicated, the new components are incompatible with the old components of all three manufacturers. Nothing is assumed at this point about the technological or economic superiority of the new system.

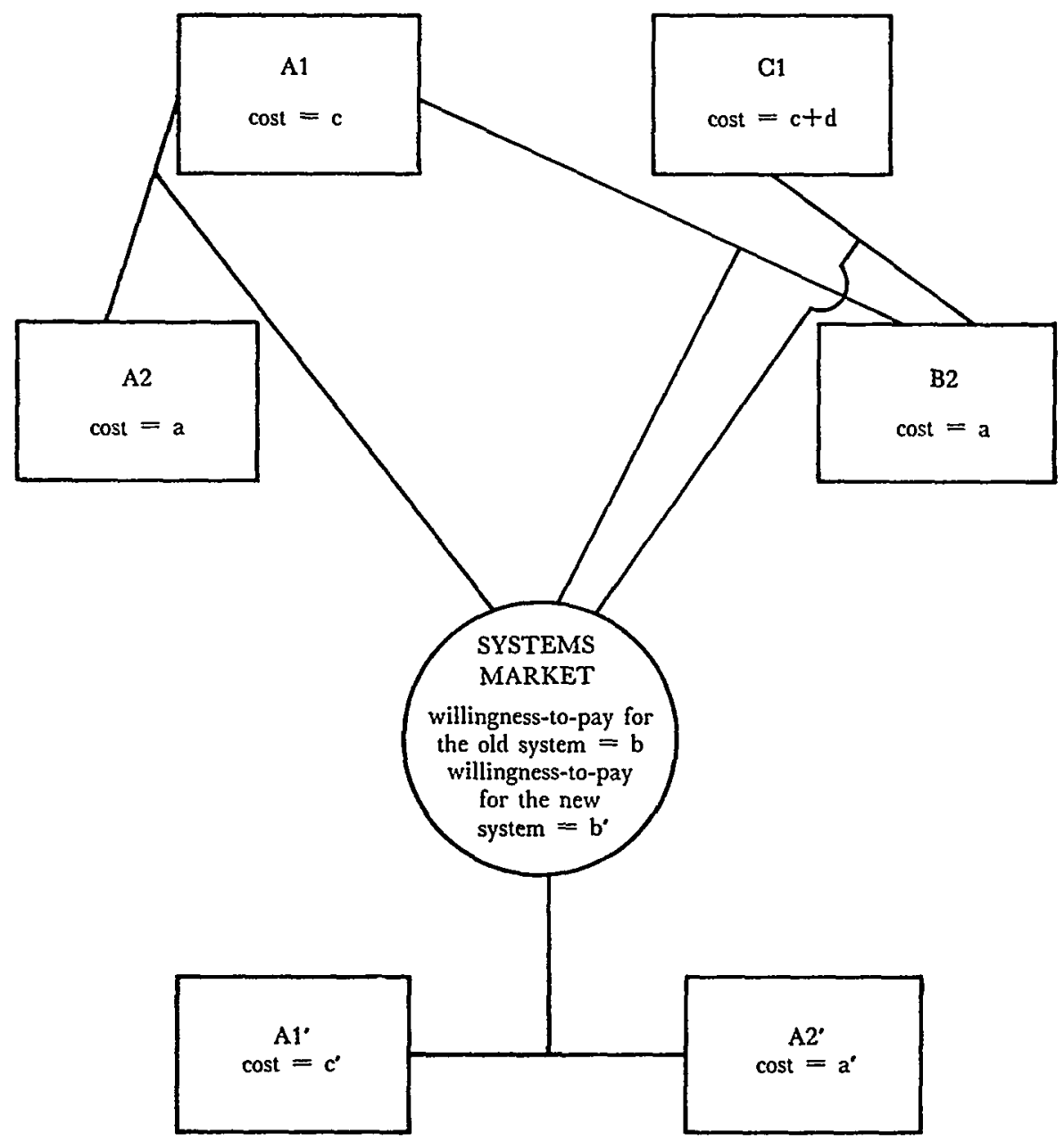

Figure 5

In this scenario, firm A can induce the exit of firm B with the following two-part tactic: First, firm A sets the price of $A 1$ at a level denoted by $p$. Second, firm A offers the new system, composed of $A 1^{\prime}$ and $A 2 '$, at a price $\mathrm{p}_{\mathrm{s}}$ that is low enough to induce all consumers to choose the new system over the preexisting system comprised of $\mathrm{A} 1$ and B2, sold at a price of $\mathrm{p}+\mathrm{a}$, and over the preexisting system comprised of $\mathrm{C} 1$ and $\mathrm{B} 2$, even if that system is sold at its cost of $c+d+a$. Thus, $p_{s}^{\prime}$ is set such that $b^{\prime}-p_{s}^{\prime}$ 
the consumer surplus ${ }^{81}$ from the new system, is greater than both $b$ $(p+a)$ and $b-(c+d+a)$, which represent the consumer surplus from the systems comprised of $\mathrm{A} 1$ and $\mathrm{B} 2$, and $\mathrm{C} 1$ and $\mathrm{B} 2$, respectively. As a consequence, the sales of component $B 2$ fall to zero, and the viability of firm $B$ is threatened. As noted above, firm A's motive for exit inducement in this scenario may be the additional monopoly profit attendant on the irreversible exit of firm $B$.

To determine whether predatory profit sacrifice has occurred, one must inquire whether a price for $\mathrm{A} 1$ lower than $p$, the price actually charged, would be less damaging to firm $B$ and would increase the profit of firm $A$ given the continued viability of firm $B$. Due to the presence in the market of the component $\mathrm{C} 1$, firm $\mathrm{B}$ is viable ${ }^{82}$ until the dispersal of its productive assets. Thus, the test for profit sacrifice can utilize data from the time period between the introduction of the new system and the exit of firm $B$.

During this period, a price for component $\mathrm{A} 1$ that induces the exit of firm B eliminates sales of both B2 and A1. Hence, if a lower price for A1 would stimulate sales of $\mathrm{A} 1$ at a markup greater than the markup on the diverted sales of the new system, the actual price of A1 entails predatory profit sacrifice.

The price of A1 that compensates firm A for lost sales of the new system, the compensatory price, can be calculated as follows: ${ }^{33}$ The profit on

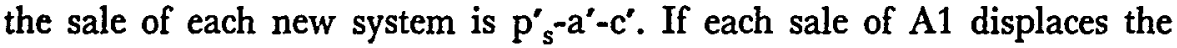
sale of one new system, then the compensatory price must provide firm $A$ with a profit per unit just equal to the lost profit on a new system. Thus, because the cost of $A 1$ is $c$, the compensatory price is $c+p_{s}^{\prime}-a^{\prime}-c^{\prime}$. Firm $A$ is guilty of predatory profit sacrifice if it refuses to reduce the price of $\mathrm{A1}$ to this compensatory level, and maintains instead a higher actual price, thereby choking off all sales of A1.

Of course, the compensatory price for A1 may be above its actual price of $p$. A price for A1 that induces the exit of firm B, however, can be less than or equal to the compensatory price if and only if the new system is economically superior to the old system, without consideration (yet) of the R\&D costs for the new system. ${ }^{84}$ Thus, in this model of systems rivalry,

81. Consumer surplus is equal to the difference between the maximum amount that a consumer will pay for a given quantity of a good and the amount actually paid for that quantity of the good. See Willig, Consumer's Surplus Without Apology, 66 AM. ECON. REV. 589 (1976).

82. See pp. 41-42 supra.

83. Alternatively, the compensatory price can be calculated as the price that yields the same markup on $\mathrm{A} 1$ as the markup on the parallel new component, $\mathrm{A} 1^{\circ}$, when the latter markup is calculated conservatively. See note 77 supra. Both calculations yield the same result.

84. Specifically, one can find values of $p$ and $p_{s}^{\prime}$ such that (i) $b-(p+a)<b^{\prime}-p_{s}^{\prime}$; (ii) $b-(c+d+a)$ $<b^{*}-p_{s}^{*}$; and (iii) $p<c+p_{s^{\prime}}^{-}-a^{\prime}-c^{\prime}$, if and only if $b^{\prime}-\left(c^{\prime}+a^{\prime}\right)>b-(c+a)$. Condition (i) is that consumers prefer the new system to $\mathrm{A} 1$ and $\mathrm{B} 2$, when $\mathrm{B} 2$ is priced at cost; (ii) is that consumers prefer the new system to $\mathrm{C} 1$ and $\mathrm{B} 2$, when they are both priced at cost; and (iii) is that the price of $\mathrm{A} 1$ does 
the compensatory price test protects social welfare.

To establish this proposition, assume first that $b^{\prime}-\left(c^{\prime}+a^{\circ}\right)$, the net social benefit from the production and consumption of a new system (exclusive of initial $R \& D$ outlays), exceeds $b-(c+a)$, the corresponding net social benefit from the old system. Then, firm A can induce the exit of firm $B$ by setting $\mathrm{p}_{\mathrm{s}}^{\prime}$ just below $\left(b^{\prime}-b\right)+(c+d+a)$, while setting $p$ at the corresponding compensatory level just below $\left(b^{\circ}-\left(c^{\prime}+a^{\prime}\right)\right)-(b-(c+a))+(c+d) .^{85}$ These exit-inducing prices have the following interpretation: the new system price, $\mathrm{p}_{\mathrm{s}}$, is just below the cost of producing a system comprised of components manufactured by A's rivals, $(c+d+a)$, plus consumers' evaluation of the quality advantage of the new system over the old system, (b'b). Thus $\left(b^{\prime}-b\right)+(c+d+a)$ is the maximum amount that consumers are willing to pay for the new system if the rivals of firm A, firms B and C, are viable competitors in the systems market. The corresponding compensatory price for $\mathrm{A} 1$ is equal to the difference between the maximum profit that can be earned on the sale of a new system, $\left(b^{\prime}-\left(c^{\prime}+a^{\prime}\right)\right)$, and the maximum profit on the sale of an old system, (b-(c+a)), plus the cost of the inferior supplier, $(c+d)$. Note that $\left(b^{\prime}-\left(c^{\prime}+a^{\prime}\right)\right)$ and $(b-(c+a))$ also represent the net social benefits, exclusive of $R \& D$ costs, from a new and an old system, respectively, and that $c+d$ is the maximum price that firm A can charge for A1 in the face of competition from C1. Thus, the compensatory price yields to firm A the maximum possible price for A1 given the viability of firm $\mathrm{C},(\mathrm{c}+\mathrm{d})$, plus a profit increment equal to the difference in potential profitability between a sale of the new system and a sale of the old system. If that profit increment is positive, as postulated above, the compensatory price is above $(c+d)$.

At these prices for A1 and for the new system, firm B cannot sell B2 at any price at or above production cost, because the consumer's surplus from the $\mathrm{C} 1, \mathrm{~B} 2$ system offered at cost, $b-(c+d+a)$, is just below the consumer's surplus from the new system, $\mathrm{b}^{\prime}-\mathrm{p}_{\mathrm{s}}^{\prime}$. Moreover, because the actual price for A1, $p$, (through compensatory) is above ( $c+d$ ), consumers prefer $\mathrm{C} 1$ offered at $(\mathrm{c}+\mathrm{d})$ to $\mathrm{A} 1$ offered at $p$. Thus, firm $\mathrm{A}$ can induce the exit of firm B without violating the compensatory price test.

not exceed its compensatory level. The relationship $b^{\prime}-\left(c^{\prime}+a^{\prime}\right)>b-(c+a)$ implies that the net social benefit from the production and consumption of a new system exceeds that from the old system. The truth of this proposition can be established by straightforward algebra.

85. Firm A earns a profit of $\mathrm{p}_{\mathrm{s}}^{\prime}-\left(\mathrm{a}^{\prime}+\mathrm{c}^{\prime}\right)$ on each sale of the new system. Given the hypothesized value of $p_{s^{\prime}}^{\prime}$, the profit on such a sale is $\left(b^{\prime}-b+c+d+a\right)-\left(a^{\prime}+c^{\prime}\right)$. Firm A loses one sale of a new system for every consumer purchase of an old system comprised of one unit of B2 or A2 and one unit of A1. Consequently, in the absence of anticompetitive objectives, firm A willingly would sell A1 at a markup at least equal to the profit lost on a diverted sale of the new system. If $p$ is the price of $A 1$, then firm A earns a profit of $p-c$ on each sale of A1. Hence, if $p$ is set compensatorily, $p-c$ will equal $\left(b^{\prime}-b+c+d+a\right)-\left(a^{\prime}+c^{\prime}\right)$. From this equality, the compensatory level of $p$ can be calculated as ( $b^{\circ}-$ $\left.\left(a^{\prime}+c^{\prime}\right)\right)-(b-(a+c))+(c+d)$, as stated in the text. 
Now assume that the old system is economically superior to the new system, even without accounting for the $R \& D$ costs of the new system, so that $b-(c+a)$ exceeds $b^{\prime}-\left(c^{\prime}+a^{\prime}\right)$. Then, firm A cannot induce firm B's exit without violating the compensatory price test. Suppose first that firm A sets the price of $A 1, p$ above $c+d$, so that $\mathrm{C1}$, sold at cost, is preferred to A1. To induce all consumers to purchase the new system rather than the system comprised of $\mathrm{C} 1$ and $B 2$, firm A must then set $p_{s}^{\prime}$ such that $b^{\prime}-$ $\mathrm{p}_{\mathrm{s}}^{\prime}$ exceeds $\mathrm{b}-(\mathrm{c}+\mathrm{d}+\mathrm{a})$ - that is, such that the consumer surplus from a new system exceeds the consumer surplus from an old system comprised of $\mathrm{C} 1$ and B2. Therefore, $\mathrm{p}_{\mathrm{s}}^{\prime}$ must be less than $\mathrm{b}^{\prime}-\mathrm{b}+\mathrm{c}+\mathrm{d}+\mathrm{a}$, which is the maximum amount that consumers are willing to pay for the new system if the old system is sold at cost. Consequently, the corresponding compensatory price of $A 1, p^{\prime} s^{-} a^{\prime}-c^{\prime}+c$, must be less than $\left(b^{\prime}-b+c+d+a\right)-a^{\prime}-$ $c^{\prime}+c$. The latter expression is equivalent to $(c+d)+\left(b^{\prime}-a^{\prime}-c^{\prime}\right)-(b-a-c)$, which is less than $(c+d)$ under the hypothesis that $(b-a-c)$ exceeds $\left(b^{\prime}-a^{\prime}-\right.$ $\left.c^{\prime}\right)$. Hence, the compensatory price of $\mathrm{A} 1$ is less than $c+d$, and because (by hypothesis) the actual price, $p$, is above $c+\mathrm{d}$, the actual price of $\mathrm{A} 1$ exceeds the compensatory price. Thus, if firm A sets $p$ above $(c+d)$, and sets $\mathrm{p}_{\mathrm{s}}$ to divert all sales from the economically superior old system, the price of $\mathrm{A} 1, p$, fails the compensatory price test.

Suppose instead that firm A sets $p$ below $c+d$, so that the systems comprised of $\mathrm{A} 1$ and $\mathrm{B} 2$ or A1 and A2 are the consumers' best alternatives to the new system. Then, for firm A to drive the demand for B2 to zero, $\mathrm{p}_{\mathrm{s}}$ must be set such that $b^{\prime}-p^{\prime}{ }_{s}$ exceeds $b-(p+a)$-that is, such that the consumer surplus from a new system exceeds the consumer surplus from an old system comprised of $\mathrm{A} 1$ and either $\mathrm{A} 2$ or $\mathrm{B} 2$. If $\mathrm{b}^{\prime}-\mathrm{p}_{\mathrm{s}}^{\prime}$ exceeds $\mathrm{b}-$ $(p+a), p$ exceeds $p_{s}^{\prime}+b-a-b^{\prime}$. But the latter quantity exceeds the compensatory price for $A 1, p^{\prime}{ }^{\prime}-a^{\prime}-c^{\prime}+c$, by $(b-c-a)-\left(b^{\prime}-c^{\prime}-a^{\prime}\right)$, which (by hypothesis) is positive. Hence, if firm A sets $p$ below $(c+d)$ and sets $p_{s}^{\prime}$ in order to divert all sales from the economically superior old system, the price of A1 again fails the compensatory price test.

In summary, firm A can set prices such that: all consumers prefer the new system to the old; firm B is driven from the market; and the price of A1 satisfies the compensatory price test, if and only if the displacement of the old system by the new system is socially beneficial, treating R\&D costs for the new system as sunk costs that cannot be recovered.

\section{b. Research and Development Costs}

The second part of the test for predatory profit sacrifice examines the motive for the R\&D investment in the new system. The proposed general standard implies that $R \& D$ expenses are not predatory if they are less than the anticipated additional net revenues made possible by the innova- 
tion, given a compensatory price for A1. Assume, in the context of the model above, that $b^{\prime}-\left(c^{\prime}+a^{\prime}\right)$ exceeds $b-(c+a)$, so that the induced exit of firm $B$ is consistent with compensatory pricing of A1.

Firm A's net revenues are maximized by the highest level of $p_{s}^{\prime}$ that is feasible with the continued viability of firms $B$ and $C$, i.e., $b^{\prime}-b+c+d+a$. The corresponding net revenue per system is $\left(b^{\prime}-b+c+d+a\right)-\left(a^{\prime}+c^{\prime}\right)$, or $\left(b^{\prime}-a^{\prime}-c^{\prime}\right)-(b-a-c)+d$. Absent the development of the new system, the maximum net revenue available to firm $A$ is $d$ per system. Therefore, the incremental net revenue per system attributable to the innovation, under the continued viability premise, is the difference between these two figures- $\left(b^{\prime}-c^{\prime}-a^{\prime}\right)-(b-c-a)$.

The test for predatory sacrifice is whether this difference in net revenue per system, as anticipated at the time of the R\&D investment decision, is large enough to justify the $R \& D$ outlay. If so, then the $R \& D$ investment is justified by an innocent profit motive, even though it results in the exit of firm B. If not, however, only predatory objectives can rationalize the R\&D expenditures. This test coincides exactly with the test of whether the R\&D investment is socially warranted; the social benefits from the displacement of the old system by the new system exceed the costs of the innovation if and only if $\left(b^{\prime}-c^{\prime}-a^{\prime}\right)-(b-c-a)$ times the number of systems customers exceeds the R\&D expense. ${ }^{86}$

Thus, the proposed tests for compensatory pricing and for the $R \& D$ motive conduce to social welfare. They permit socially desirable innova-

86. The results in the text implicitly assume that the production costs of A1 are not changed by the introduction of the new system. If the production costs of A1 change due to the introduction of the new line, however, say from $c$ to $e$, the tests remain socially optimal if modified slightly. Specifically, one can show that there exist values of $p_{S}^{\prime}$ and $p_{1}$ (the new price of $A 1$ ) such that (i) $p_{s}^{\prime} \geq a^{\prime}+c^{\prime}$; (ii) $b^{\prime}-p_{s}^{\prime} \geq b-(a+c+d)$; (iii) $b^{\prime}-p_{s}^{\prime} \geq b-\left(a+p_{1}\right)$; and (iv) $p_{1}-e \geq p_{s}^{\prime}-\left(a^{\prime}+c^{\prime}\right)$ if and only if (v) $b^{\prime}-$ $\left(a^{\prime}+c^{\prime}\right) \geqq b-(a+e)$ and $(v i) b^{\prime}-\left(a^{\prime}+c^{\prime}\right) \geqq b-(a+c+d)$. The interpretations of these relationships are as follows: (i) the new system is priced at or above production costs; (ii) the consumer surplus from the new system equals or exceeds that from $\mathrm{C} 1$ and $\mathrm{B} 2$ sold at cost; (iii) the consumer surplus from the new system equals or exceeds that from A1 and B2; (iv) the markup on A1 relative to its new cost does not exceed that on the new system, so that $p_{1}$ is not supra-compensatory; and $(v)$ and (vi) the net social benefits from the consumption and production of the new system equal or exceed those from an old system comprised of either $A 1$ and $B 2$ or $\mathrm{C} 1$ and $\mathrm{B} 2$, where the relevant cost of $\mathrm{A} 1$ is its new level, $e$. Thus, firm A can induce the exit of firm B by diverting all sales to the new system with prices that are compensatory and cover costs, if and only if the new system is socially preferable to the old system, without consideration of R\&D costs, and with reference to the new level of production costs for the old system.

One can also show that firm A's profit-maximizing prices, among those that cover production costs, are compensatory, and divert all sales to the new system (that is, which satisfy (i)-(iv) above), yicld profits equal to $N\left[\left(b^{\prime}-a^{\prime}-c^{\prime}\right)-(b-a-c-d)\right]-R$, where $N$ is the number of system customers. Because the maximum profits from the old system are $N d$, the change in the innovator's profits is $N\left[\left(b^{\circ}-a^{\prime}-c^{\prime}\right)\right.$ (b-a-c)]-R, given compensatory prices not below costs, and the continued viability premise. This quantity is exactly equal to the change in net social benefits attributable to the innovation. Hence, when production costs for the old components are altered by the innovation, the proposed tests for predation promote social welfare if they are augmented by the stipulation that the price of the new system must cover its production costs. 
tions, whatever their effects on market structure, and they simultaneously restrain socially wasteful innovations whose only motivation is the additional monopoly profits attendant on their anticompetitive effects. For example, if the new system is technologically inferior to the old one, and if its incremental production cost is not substantially lower, then the compensatory price for the old component enables an equally efficient rival to sell the old system at a price that yields consumers greater net benefits than the purchase of a new system. Thus, the predatory and socially wasteful R\&D investment in the new system is deterred.

Moreover, the technological superiority of a new system does not preclude a finding of predatory product innovation. Instead, the requisite R\&D investment must be scrutinized for the underlying motive by comparing the anticipated costs of the innovation with its anticipated incremental net revenues, calculated on the premise that the rival has continued access to necessary preexisting components. Under this standard, a new system is immune from a finding of predation if and only if the value to consumers of the new system relative to the preexisting system is greater than the required development costs. ${ }^{87}$

\section{An Alternative Test}

Another test for predatory product introduction is applicable in some special circumstances. This test inquires whether an alternative, less exclusionary design of the new product would yield a higher incremental profit to the innovator than the design actually chosen, under the premise of the continued viability of the rival. More often than not, this test is too speculative to be of legal value, but in some instances an alternative design that is less exclusionary, less costly, and no less desirable to consumers may be evident. ${ }^{88}$ The decision by a defendant to reject such a design en-

87. Concededly, the optimality properties of the proposed tests have not been formally analyzed in models more general and complex than those developed in the text.

88. In a recent case, the plaintiff urged the court as part of the predation test to incorporate the profits that the innovator sacrificed by selecting the actual product design over an available less exclusionary design. Transamerica Computer Co. y. IBM, 459 F. Supp. 626 (1978). In that case the plaintiff, Transamerica, argued that to test for predatory profit sacrifice it is necessary "to subtract from the profits IBM predicted it would realize on a particular product the estimated profits that might have been realized on a product that could have been produced in its stead." Id. at 631 . These forgone profits are referred to as opportunity costs. Id. Judge Schnacke ruled that the use of the concept of opportunity costs is improper as a matter of law. Id.

The analysis in this article suggests that the positions taken by TCC and by Judge Schnacke are both incorrect. In contrast to the rule proposed by Transamerica, our standard implies that the relevant comparison is between the profits the discarded design would have earned under the premise of the continued viability of the innovator's rivals and the profits that the adopted design would have earned under the same premise. And, contrary to Judge Schnacke's ruling, our analysis shows that if the correctly calculated opportunity costs are sufficiently large, then the chosen product design may entail predatory profit sacrifice, which is the hallmark of predatory behavior. At the same time, Judge Schnacke correctly recognized that calculation of the profits that would be generated by an alternative 
tails a predatory sacrifice of profit.

When applicable, this test also promotes social welfare. Specifically, an exclusionary new design is socially preferable to an alternative design that is compatible with a rival's component, if and only if the former would be more profitable than the latter under the continued viability premise, with preexisting components offered at compensatory prices, and net of $R \& D$ costs. ${ }^{89}$ Thus, an exclusionary design may be socially optimal even if a less-exclusionary alternative design exists. On the other hand, an exclusionary design may be motivated by the prospect of additional monopoly power attendant on the exit of a rival. Such designs waste social resources and entail a predatory profit sacrifice.

\section{The Burden of Proof}

Although antitrust scrutiny of product innovation in principle can promote social welfare, ${ }^{90}$ the possibility exists that judicial adoption of the proffered standard might spur excessive, costly litigation over product innovations. In our opinion, however, the danger of excessive litigation is small due to the burden of proof that the standard places on prospective

product design may be highly speculative. For this reason, if a chosen design earns at least a normal rate of profit under the premise of continued viability, it perhaps should be viewed as free of predatory profit sacrifice, unless there is an evident alternative that is less exclusionary and clearly more profitable under the viability premise. See Berkey Photo, Inc. v. Eastman Kodak Co., 603 F. 2d 263, 288-89 (2d Cir. 1979), cert. denied, 100 S. Ct. 1061 (1980); Note, An Economic and Legal Analysis of Physical Tie-Ins, 89 YALE L.J. 769, 793-94 n.115 (1980).

89. As shown above, see note 85 supra, if the preexisting component, $\mathrm{A} 1$, is available to the rival at a compensatory price, the maximum profits per system customer that the innovator can earn (gross of $R \& D$ costs) from the exclusionary new system are $\left(b^{\prime}-a^{\prime}-c^{\prime}\right)-(b-a-c)+d$. This quantity must be compared with the maximum profit that the innovator can earn from an alternative new design that is compatible with the rival's component, B2. Let the consumers' willingness-to-pay for this alternative system equal $b^{\prime \prime}$, let the production cost of the alternative monopolized component, A1", equal $c^{\prime \prime}$, and let the R\&D costs of this component equal $R^{\prime \prime}$. Because A1" is compatible both with B2 and A2, the introduction of the alternative system would not endanger the viability of firm $B$, would not require firm $A$ to maintain a compensatory price for $A 1$, and would not affect the competitive price of a for both B2 and A2. The maximum price at which the new system can be sold is $p_{s}^{\prime \prime}$, where $b^{\prime \prime}-p_{s}^{\prime \prime}$ $=\mathrm{b}-(\mathrm{c}+\mathrm{d}+\mathrm{a})$; at a higher price, consumers would derive greater consumer surplus from purchasing the old system, $\mathrm{C} 1$ and $\mathrm{B} 2$, sold at cost. Thus, $\mathrm{p}_{\mathrm{s}}^{\prime \prime}=\mathrm{b}^{\prime \prime}-\mathrm{b}+(c+d+a)$. The corresponding profit on the alternative system is $\mathrm{p}^{\prime \prime}-\mathrm{c}^{\prime \prime}-\mathrm{a}=\left(\mathrm{b}^{\prime \prime}-\mathrm{a}-\mathrm{c}^{\prime \prime}\right)-(\mathrm{b}-\mathrm{a}-\mathrm{c})+\mathrm{d}$ per systems customer, less the total $R \& D$ costs $\mathrm{R}^{\prime \prime}$. The innovator can earn all of this profit by selling $\mathrm{A} 1^{\prime \prime}$ for $\mathrm{p}_{\mathrm{s}}$ - $\mathrm{a}$, or by selling bundled systems for $\mathrm{p}_{\mathrm{s}}$. Consequently, the difference between the innovator's profits from the exclusionary design under the continued viability premise and the innovator's profits from the alternative design is $\left(b^{\prime}-a^{\prime \prime}-c^{\prime}\right)-\left(b^{\prime \prime}-a-c^{\prime \prime}\right)$ per systems customer, less the difference in $R \& D$ costs, (R-R"). This is precisely equal to the difference between the net social benefits from the consumption, production, and development of the two system designs.

90. In the model that we have analyzed in this article, the only possible cause of social inefficiency is predatory behavior. We conjecture that this implicit assumption enables our proposed tests to achieve social optimality. In fact, however, there are other causes of social inefficiency aside from predation. See note 57 supra (discussing other reasons why profitable product introductions may be socially inefficient). We would not be surprised or disillusioned to discover that our proposed tests may sometimes ameliorate and may sometimes exacerbate the social inefficiency caused by other imperfections in market performance. 


\section{Predatory Product Innovation}

plaintiffs.

First, the standard narrowly limits the circumstances in which the behavior of an innovating firm is to be examined. Moreover, because innovation is generally beneficial, the plaintiff should carry the burden of establishing the preconditions for the scrutiny of behavior. Thus, under our standard the plaintiff must establish that the defendant possesses monopoly power over certain system components; that there are entry hurdles and reentry barriers into the final systems market and into the production of relevant individual components; and that the rival's exit would substantially weaken competition in the systems market.91 In addition, the plaintiff must convincingly show that the rival's exit ${ }^{22}$ from the systems market is likely, ${ }^{93}$ and that the defendant's actions substantially increase the likelihood of exit.

If the plaintiff alleges that the defendant's repricing or withdrawal of complementary components is predatory, the plaintiff must show that the components are in fact vital to the viability of the defendant's rivals. Thus, the components must be shown to be strongly complementary to those of the rivals, and to be the most preferred complements of the rival's offerings (even in relation to alternatives that the rival could produce himself).

If the plaintiff establishes all of the aforementioned facts, he then may argue that the defendant's post-innovation behavior entails predatory profit sacrifice. One way for the plaintiff to succeed in this argument is to demonstrate that the defendant's rival (or his customers) was willing to purchase compatible components at prices that were at least compensatory, but that the defendant was unwilling to sell the components at such prices. ${ }^{94}$ Alternatively, if the plaintiff cannot show that the defendant vio-

91. The proposed standard avoids the repression of socially valuable innovations by defining the relevant market as the market for systems, not the market for components that are compatible with those of the alleged predator. The narrower market definition would erroneously suggest that the introduction of a new system may be anticompetitive merely because it creates incompatibilities between the products of the rival and those of the alleged predator. Innovators require temporary, quasimonopoly profits from new designs to recover R\&D investments, see app. infra, and hence a focus on the creation of incompatibilities is inappropriate.

92. Exit may entail either the dispersal of the rival's productive assets or the unavailability of components that are compatible with the rival's components. See pp. 41-42 supra.

93. The social costs of litigation under our standard will be smaller, the more demanding are the burden of proof requirements imposed on the plaintiff. The procompetitive benefits from the application of our standard, however, derive from the forestalled exit of socially desirable competitors. We feel that an appropriate balance is struck by requiring a truly dangerous probability of exit; such a requirement would prevent excessive litigation without destroying the standard's efficacy.

94. The requirement that the innovator offer to sell the old components at compensatory prices may appear quite harsh, but in fact the opposite is true. First, even if the monopolist refuses to provide the needed components at compensatory prices, he can nevertheless defend against a charge of predation by showing that his refusal was part of a bargaining strategy designed to secure supracompensatory prices for the components. For this defense to be credible, the monopolist must demonstrate that he and his rivals engaged in good-faith bargaining over the relevant prices.

Second, the offer to sell at a compensatory price need only be of limited duration. If rivals do not 
lated the compensatory price test, he may prove that the R\&D investment was anticompetitive, in that it entailed a predatory profit sacrifice. Whichever argument the plaintiff makes, however, he should carry the burden of proof, to discourage socially wasteful litigation, to conserve judicial resources, and to avoid chilling the innovative process.

\section{Conclusion}

This article has proposed an economic definition of predation, and has derived from that definition workable tests for predatory price-cutting and product innovation. These tests go beyond existing tests for predation to encompass conduct that has proven troublesome to analyze in the past. The new tests enhance social welfare by deterring exit-inducing anti-competitive conduct, without deterring procompetitive conduct, and without stimulating excessive litigation.

\section{Appendix: Product Preannouncements}

Often, to inform consumers about a new product, an innovator preannounces the product before it becomes commercially available. In several recent cases, the innovator's timing of the announcement has been challenged as an anticompetitive tactic.95

In at least one instance, a product announcement was alleged to be anticompetitive because it was made substantially ahead of the actual introduction of the new product. ${ }^{96}$ In other instances, however, announcements were attacked for precisely the opposite reason-because they were not issued sufficiently ahead of

avail themselves of the option during twelve months, say, the offer can be discontinued without further culpability. Concededly, this rule raises the possiblity that the innovator will set the price of the new system low during the period the offer is in force, only to raise it when the offer expires. For two reasons, however, this danger is not terribly worrisome. First, compensatory prices are linked to the prices of new components-if the latter prices decline, so do the former prices-and hence a temporary reduction in the price of the new system confers a benefit on the rival in terms of a lower compensatory price. Second, if the price of the new system is set low, the price structure may fail the predation test that requires that the $R \& D$ investment yield sufficiently large incremental profit.

Finally, the compensatory pricing rule is not unduly burdensome on the innovator because compensatory prices are determined on the basis of current unit costs. These costs include any capital costs that are attributable to the provision of capital equipment; if the capital equipment used to produce the old components is also used to produce the new system, it may be more scarce and congested than prior to the innovation. If so, the compensatory price increases. Also, to assure that capital costs for the production of the old component will be covered, the innovator may require a long-term purchase agreement.

95. Berkey Photo, Inc. v. Eastman Kodak Corp., 603 F.2d 263 (2d Cir. 1979), cert. denied, 444 U.S. 1093 (1980); United States v. IBM, No. 69-200 (S.D.N.Y., filed Jan. 12, 1969) (Complaint at 20-21); ILG Periperals Leasing Corp. v. IBM, 458 F. Supp. 423, 436 (N.D. Cal. 1978), affd sub nom. Memorex Corp. v. IBM, 636 F.2d 1188 (9th Cir. 1980). See generally Note, Berkey Photo, Inc., v. Eastman Kodak Co.: The Predisclosure Requirement-A New Remedy for Predatory Marketing of Product Innovations, 10 RUT.-GaM. L.J. 395 (1979).

96. See U.S. v. IBM, No. 69-200 (S.D.N.Y., filed Jan. 12, 1969)(Complaint at 20-21). 


\section{Predatory Product Innovation}

the actual introduction of the new product. ${ }^{97}$

This disparity of views as to the proper timing of announcements portends the difficulty of developing workable tests for the legality of product announcements. Under the standard proposed in this article, the trier of fact would have to determine whether the timing of the announcement would have been different had the innovator assumed the continued viability of the rival.

Although several considerations determine the timing of a product announcement, one possibly anticompetitive consideration is the negative effect that a preannouncement can have on the revenues of a rival. If, as a result of an early announcement, prospective buyers postpone their purchases until the new model becomes commercially available, rivals may experience substantial reductions in their cash flows, and their viability may be endangered. Moreover, if the innovator anticipates that a rival may exit, a product announcement may be advanced for several reasons. If the rival exits before the new product is introduced, some sales are diverted to the preexisting products of the innovator that compete with the rival. To some extent, this gain offsets the loss of sales to consumers who react to the preannouncement of the new product by postponing their purchases. Second, the incremental profit on the new product is increased by the early exit of rivals because some of their sales are diverted to the new offering. Hence, the anticipated exit of rivals may increase the benefits and reduce the costs of early preannouncement, and to this extent, exit inducement may be a motive for early preannouncement.

On the other hand, early preannouncement of an innovation may be procompetitive. If the new product is part of a system, the innovator may wish to provide other firms with the lead time necessary to the production of complementary components. Moreover, even under the continued viability premise, it may be profitable to inform consumers of a forthcoming innovation to encourage them to postpone their purchases. Accurate information of this kind can benefit consumers by promoting better planning and decisionmaking.

Other legitimate considerations, however, justify delay in the timing of a product announcement. Because an innovator requires a temporary "quasi-monopoly" on new products to recoup the costs of $R \& D$, preannouncement may deprive him of the necessary lead time over his competitors. Thus, to require preannouncements may repress socially beneficial innovation.

We conclude, therefore, that any timing of a product preannouncement should be presumed legal. The diversity of considerations that underlie the decision to predisclose the new product make it impossible to fashion an implementable test for anticompetitive product preannouncements. Furthermore, the need for such a test is substantially reduced by a requirement that innovating firms provide their rivals with complementary components at compensatory prices.

97. Berkey Photo, Inc. v. Eastman Kodak Corp., 603 F.2d 263 (2d Cir. 1979), cert. denied, 444 U.S. 1093 (1980); ILC Peripherals Leasing Corp. v. IBM, 458 F. Supp. 423, 436 (N.D. Cal. 1978), aff'd sub nom. Memorex Corp. v. IBM, 636 F.2d 1188 (9th Cir. 1980). 